\title{
Methodiek arbeidsmarktprognoses en -indicatoren 2001-2006
}

Citation for published version (APA):

Cörvers, F., Marey, P. S., Hensen, M. M., Golsteyn, B. H. H., \& Diephuis, B. J. (2002). Methodiek arbeidsmarktprognoses en -indicatoren 2001-2006. Researchcentrum voor Onderwijs en Arbeidsmarkt, Faculteit der Economische Wetenschappen. ROA Working Papers No. 4

https://doi.org/10.26481/umarow.2002004

Document status and date:

Published: 01/01/2002

DOI:

10.26481/umarow.2002004

Document Version:

Publisher's PDF, also known as Version of record

\section{Please check the document version of this publication:}

- A submitted manuscript is the version of the article upon submission and before peer-review. There can be important differences between the submitted version and the official published version of record.

People interested in the research are advised to contact the author for the final version of the publication, or visit the DOI to the publisher's website.

- The final author version and the galley proof are versions of the publication after peer review.

- The final published version features the final layout of the paper including the volume, issue and page numbers.

Link to publication

\footnotetext{
General rights rights.

- You may freely distribute the URL identifying the publication in the public portal. please follow below link for the End User Agreement:

www.umlib.nl/taverne-license

Take down policy

If you believe that this document breaches copyright please contact us at:

repository@maastrichtuniversity.nl

providing details and we will investigate your claim.
}

Copyright and moral rights for the publications made accessible in the public portal are retained by the authors and/or other copyright owners and it is a condition of accessing publications that users recognise and abide by the legal requirements associated with these

- Users may download and print one copy of any publication from the public portal for the purpose of private study or research.

- You may not further distribute the material or use it for any profit-making activity or commercial gain

If the publication is distributed under the terms of Article $25 \mathrm{fa}$ of the Dutch Copyright Act, indicated by the "Taverne" license above, 
Methodiek arbeidsmarktprognoses en -indicatoren 2001-2006

ROA-W-2002/4

F. Cörvers, B.J. Diephuis, S. Dijksman, B. Golsteyn, M. Hensen, Ph. Marey

Researchcentrum voor Onderwijs en Arbeidsmarkt

Faculteit der Economische Wetenschappen en Bedrijfskunde Universiteit Maastricht

Maastricht, november 2002 
ISBN 90-5321-349-X

Sec02.154.doc 


\section{Inhoud}

Pagina

Voorwoord

1 Inleiding

2 Structuur van de gepresenteerde arbeidsmarktinformatie

3 De actuele situatie op de arbeidsmarkt 5

3.1 Inleiding 5

3.2 De berekening van de trend 5

$\begin{array}{lll}3.3 \text { Toelichting op de variabelen voor de actuele situatie } & 6\end{array}$

4 Methodiek arbeidsmarktprognoses 11

$\begin{array}{ll}4.1 \text { Inleiding } & 11\end{array}$

4.2 Methodiek uitbreidingsvraag 11

4.3 Methodiek vervangingsvraag 19

4.4 Methodiek instroom van schoolverlaters op de arbeidsmarkt 26

$\begin{array}{ll}4.5 \text { Typering arbeidsmarktperspectieven } & 30\end{array}$

4.6 Typering knelpunten in de personeelsvoorziening 31

5 De structurele arbeidsmarktsituatie 33

5.1 Inleiding 33

5.2 Conjunctuurgevoeligheid 33

$\begin{array}{ll}5.3 \text { Uitwijk- en substitutiemogelijkheden } & 34\end{array}$

$\begin{array}{ll}5.4 \text { Concurrentie-index } & 35\end{array}$

$\begin{array}{ll}\text { Literatuur } & 36\end{array}$

$\begin{array}{ll}\text { Appendix A } & 39\end{array}$

$\begin{array}{ll}\text { Appendix B } & 43\end{array}$ 



\section{Voorwoord}

In dit werkdocument wordt een overzicht gegeven van de methodiek die is gehanteerd bij het opstellen van de arbeidsmarktprognoses naar opleiding en beroep tot 2006 en de bijbehorende arbeidsmarktindicatoren ten behoeve van het rapport De arbeidsmarkt naar opleiding en beroep tot 2006. Dit rapport is in november 2001 uitgebracht in het kader van het Project Onderwijs-Arbeidsmarkt van het ROA. In dit werkdocument wordt een actualisatie gegeven de beschrijving van de methodiek in Van Eijs e.a. (2000) ten behoeve de vorige uitgave De arbeidsmarkt naar opleiding en beroep tot 2004 (ROA, 1999a). Daarnaast bevat dit werkdocument een uitgebreidere toelichting op de methodiek van de vervangingsvraag.

De weergave van de methodiek in dit werkdocument heeft betrekking op het samenstellen van de arbeidsmarktinformatie over 34 bedrijfssectoren, 127 beroepsgroepen en 104 opleidingstypen die op de website van het ROA (http://www.roa.unimaas.nl) te bestellen is. Ook deze arbeidsmarktinformatie is in het kader van het Project Onderwijs-Arbeidsmarkt (POA) samengesteld, waarbij bovendien is rekening gehouden met de actualisatie van de gegevens over de werkenden op basis van de Enquête Beroepsbevolking (EBB) 2000 en 2001 van Centraal Bureau voor de Statistiek (CBS). In de ROA-classificatiegids 2002 (ROA, 2002a) worden uitgebreide overzichten gegeven van de namen en coderingen van de sectoren, beroepen en opleidingen die binnen POA gehanteerd worden en de koppelingen tussen de classificaties van het CBS en het ROA.

Voor de financiers van POA is de arbeidsmarktinformatie op het lagere aggregatieniveau kosteloos toegankelijk via internet. Het Project Onderwijs-Arbeidsmarkt wordt gefinancierd door het Centrum voor Werk en Inkomen (CWI), het Ministerie van Onderwijs, Cultuur en Wetenschappen, het Ministerie van Landbouw, Natuurbeheer en Visserij, het LDC Expertisecentrum voor Loopbaanvraagstukken, de Vereniging Kenniscentra Beroepsonderwijs Bedrijfsleven (COLO) en de BVE Raad. 



\section{Inleiding}

In het kader van het Project Onderwijs-Arbeidsmarkt (POA) maakt het Researchcentrum voor Onderwijs en Arbeidsmarkt (ROA) tweejaarlijks een analyse van de actuele situatie en de toekomstige ontwikkelingen op de arbeidsmarkt per opleidingstype en beroepsgroep. Eind november 2001 is in dit kader het rapport De arbeidsmarkt naar opleiding en beroep tot 2007 (ROA, 2001) verschenen. Dit rapport is gebaseerd op een uitgebreid arbeidsmarktinformatiesysteem waardoor een goed overzicht van de huidige en toekomstige positie van de verschillende beroepsklassen en opleidingscategorieën op de arbeidsmarkt kan worden gegeven. Daarnaast wordt het informatiesysteem door het LDC gebruikt voor diverse publicaties ten behoeve van de loopbaanoriëntatie. De arbeidsmarktinformatie in het rapport wordt meestal weergegeven op het niveau van 13 bedrijfssectoren, 11 beroepsklassen en 17 opleidingscategorieën. In het rapport wordt tevens een beknopte weergave van de gehanteerde methodiek gegeven en een beschrijving van de centrale begrippen.

In dit werkdocument wordt ingegaan op de gehanteerde methodiek bij de analyses en prognoses. Voor een aantal specifieke onderdelen van de methodiek zijn tevens afzonderlijke werkdocumenten verschenen. Om die reden wordt in dit werkdocument voor deze aspecten slechts een globaal overzicht van de gehanteerde methodiek gegeven. Voor een meer gedetailleerde beschrijving wordt verwezen naar het op het desbetreffende onderdeel toegespitste werkdocument. De uitgangspunten van het Project OnderwijsArbeidsmarkt zijn eveneens uitgebreider uiteengezet in verschillende andere publicaties. ${ }^{1}$

De opzet van dit werkdocument is als volgt. In hoofdstuk 2 wordt de structuur van het informatiesysteem besproken. Vervolgens wordt in hoofdstuk 3 ingegaan op de actuele data in het informatiesysteem. In hoofdstuk 4 wordt de prognosemethodiek besproken en in hoofdstuk 5 wordt ingegaan op de indicatoren met betrekking tot de structurele kenmerken van de arbeidsmarkt.

\section{Structuur van de gepresenteerde arbeidsmarktinformatie}

Het doel van het Project Onderwijs-Arbeidsmarkt is om inzicht te verschaffen in de actuele en de op middellange termijn verwachte situatie op de arbeidsmarkt, verbijzonderd naar beroep en opleiding. Met dit transparant maken van de arbeidsmarkt wordt beoogd dat de bij het onderwijs betrokken partijen beter inzicht hebben in de ontwikkelingen die zich afspelen in de aansluiting tussen onderwijs en arbeidsmarkt, zodat zij ook meer adequate beslissingen kunnen nemen. Hierdoor zullen discrepanties tussen vraag en aanbod op de arbeidsmarkt kunnen verminderen. Relevante betrokkenen zijn leerlingen, scholen, de overheid, de arbeidsvoorzieningsorganisatie en bedrijven. Door de verstrekte informatie kan een leerling die een studiekeuze maakt zich oriënteren op de arbeidsmarktperspectieven op het moment dat hij of zij de studie zal afronden. De structuur van de gegenereerde

1. Zie o.a. Borghans, De Grip en Willems (1995), Van Eijs en De Grip (1998), De Grip en Heijke (1998), Borghans, De Grip en Heijke (2000) en Cörvers, De Grip en Heijke (2002). 
informatie sluit hierbij aan door voor zowel beroepen als voor opleidingen kengetallen te presenteren met betrekking tot de actuele situatie op de arbeidsmarkt en de arbeidsmarktsituatie over vijf jaar. Ook voor andere partijen die betrokken zijn bij het onderwijs is het van belang dat er vooruit wordt gekeken. Dit voorkomt een pro-cyclisch beleid, dat te sterk reageert op de actuele arbeidsmarktsituatie. Naast de perspectieven voor schoolverlaters zoals die zijn weergegeven in de Indicator Toekomstige Arbeidsmarkt Perspectieven (ITA), wordt ook ingegaan op het perspectief van de werkgever. Middels de Indicator Toekomstige Knelpunten in de Personeelsvoorziening (ITKP) en de Indicator Toekomstige Knelpunten in de Personeelsvoorziening naar Beroepsgroep (ITKB) wordt aangegeven voor welke opleidingstypen en beroepsgroepen wervingsproblemen te verwachten zijn.

Het arbeidsmarktinformatiesysteem van POA is opgebouwd uit drie componenten. De informatie over de actuele situatie geeft aan hoe thans de positie van werkenden en schoolverlaters met een bepaalde opleidingsachtergrond is. Het arbeidsmarktperspectief van de verschillende opleidingstypen geeft op grond van de verwachte kwantitatieve verschuivingen in vraag en aanbod aan hoe deze positie zich de komende vijf jaar zal ontwikkelen. Ten slotte plaatsen de structurele kenmerken van de arbeidsmarktpositie de positie van een bepaalde opleiding of beroep in een ruimer perspectief.

De actuele informatie is in principe gebaseerd op gerealiseerde gegevens over het jaar (2001) of het gemiddelde van de afgelopen twee jaren (2000-2001). ${ }^{2}$ Zo wordt een beeld gegeven van de absolute en relatieve omvang van het totaal aantal werkenden in een beroepsgroep en de omvang van de potentiële beroepsbevolking en het aantal werkenden met een bepaalde opleidingsachtergrond. Deze aantallen werkenden worden vervolgens ook verbijzonderd naar persoonlijke kenmerken als geslacht, etniciteit en leeftijd en naar de functiekenmerken: vast werk, deeltijdarbeid, e.d. Voor de onderscheiden opleidingstypen wordt bovendien getracht een beeld te geven van de actuele aansluitingsproblemen op de arbeidsmarkt, zowel wat betreft het percentage werkloze schoolverlaters, als de mate waarin er sprake is van onderbenutting.

Bij de middellangetermijnprognoses wordt zowel voor beroepsgroepen als opleidingstypen het verwachte aantal baanopeningen aangegeven. Deze vraag naar nieuwkomers is uitgesplitst naar de vraag als gevolg van nieuwe banen (uitbreidingsvraag) en de vervangingsvraag. Voor de opleidingen wordt daarnaast ook de instroom van nieuwkomers op de arbeidsmarkt voorspeld, zodat vraag en aanbod aan elkaar kunnen worden gerelateerd. Op basis van deze confrontatie en de substitutieprocessen die hierdoor op gang zullen komen, wordt een indicator van de verwachte arbeidsmarktsituatie voor de onderscheiden opleidingstypen opgesteld. Op vergelijkbare wijze worden ook de verwachte knelpunten in de personeelsvoorziening in kaart gebracht, waarbij bovendien per bedrijfssector de opleidingstypen met de grootste knelpunten worden aangeduid. Ook voor de

2. Dit geldt voor het arbeidsmarktinformatiesysteem dat in de loop van 2002 geactualiseerd is. De actuele gegevens in het rapport De arbeidsmarkt naar opleiding en beroep tot 2006 zijn gebaseerd op de jaren 1999 en 2000. 
beroepsgroepen wordt een indicator opgesteld van de verwachte knelpunten in de personeelsvoorziening.

De structurele kenmerken van de arbeidsmarktpositie zijn eveneens afgeleid uit gerealiseerde gegevens. Enerzijds verdiepen deze indicatoren het inzicht in de huidige arbeidsmarktpositie. Anderzijds zijn deze indicatoren een aanvulling op de prognoses, doordat ze aangeven in hoeverre een beroep c.q. opleiding afhankelijk is van de ontwikkeling in een enkele bedrijfssector of beroepsgroep, in hoeverre het beroependomein van een opleidingstype gerelateerd is aan het beroependomein van andere opleidingstypen en in welke mate de werkgelegenheid gevoelig is voor de conjuncturele ontwikkelingen. Op deze wijze fungeren deze indicatoren als risico-indicatoren.

Binnen het informatiesysteem worden de actuele data, de prognoses en de structurele kenmerken telkens op kwalitatieve wijze getypeerd. Met uitzondering van de indicatoren voor de toekomstige arbeidsmarktsituatie wordt hierdoor aangegeven wat op het desbetreffende punt de relatieve positie van het beroep of de opleiding is ten opzichte van de andere beroepen, respectievelijk opleidingen. Doorgaans vinden de typeringen plaats op basis van een vijf-puntsschaal, lopend van erg hoog, hoog, gemiddeld, laag, tot erg laag. De kwalitatieve typering zorgt ervoor dat de cijfers eenvoudiger zijn te interpreteren en dat schijnnauwkeurigheden worden vermeden. De typeringen hebben plaatsgevonden op basis van een methodiek beschreven in Wieling, De Grip en Willems (1990). Daarbij wordt tevens enigszins van deze procedure afgeweken door de berekende grenzen tussen de typeringsintervallen af te ronden. In appendix A wordt voor alle variabelen in het informatiesysteem aangegeven welke grenzen zijn gehanteerd bij de kwalitatieve typering.

Bij de gepresenteerde informatie per beroepsgroep en opleidingstype wordt er ook een expliciete relatie gelegd tussen beroepen en opleidingen. Per opleidingstype wordt een overzicht gegeven van de belangrijkste beroepsgroep waarin men werkzaam is en voor elke beroepsgroep wordt de opleidingsachtergrond van de werkenden in beeld gebracht. Een vergelijkbare relatie is ook gelegd tussen bedrijfssectoren en beroepsgroepen of opleidingstypen.

Voor gebruikers van de arbeidsmarktinformatie is het doorgaans wenselijk om de beroepen en de opleidingen op een zo gedetailleerd mogelijk niveau in beeld te brengen. Deze detaillering kent echter haar grenzen in de beschikbaarheid van de basisgegevens, die voor een groot deel afkomstig zijn uit de Enquête Beroepsbevolking (EBB) van het Centraal Bureau voor de Statistiek (CBS). De onzekerheidmarges waarmee de EBB-cijfers zijn omgeven leggen een ondergrens op aan de mate van detaillering die in het informatiesysteem voor beroepen en opleidingen kan worden toegepast. Voor de EBB-gegevens geldt een ondergrens voor de aantallen personen die in de tabellen gepubliceerd mogen worden. Voor jaarcijfers is dat minimaal 5.000 werkenden, voor meerjaarsgemiddelden is dat 
minimaal 2.500 werkenden. $^{3}$ Waar deze ondergrens niet werd bereikt is in de overzichtstabellen in de Statistische Bijlage het betreffende getal met een '-' aangegeven. Andere belangrijke informatiebronnen zijn de schoolverlatersenquêtes RUBS, HBO-Monitor en de WO-Monitor, welke tezamen beschikbaar zijn in het SchoolverlatersInformatieSysteem (SIS, zie ROA 2002b). Bij de presentatie van gegevens uit deze databestanden is een ondergrens van 15 respondenten gehanteerd.

Voor de bruikbaarheid van de prognoses, actuele informatie en indicatoren is het van belang dat de gehanteerde opleidingsindeling zo goed mogelijk aansluit bij de op de arbeidsmarkt bestaande deelmarkten. Heijke, Matheeuwsen en Willems (2002) hebben daarom de opleidingsrichtingen vanuit een arbeidsmarktperspectief geclusterd. Er worden thans 113 opleidingstypen onderscheiden, die gekoppeld zijn aan de Standaard Onderwijsindeling 1978 (SOI '78) van het CBS. In totaal wordt voor 104 opleidingstypen actuele informatie en arbeidsmarktprognoses verstrekt. De gegevens met betrekking tot het MBO-niveau uit zowel de EBB als de schoolverlatersenquêtes zijn gebaseerd op de in de Wet Educatie en Beroepsonderwijs (WEB) onderscheiden leerwegen. Hiervoor werd reeds in De arbeidsmarkt naar opleiding en beroep tot 2004 gebruik gemaakt van nieuwe opleidingsbenamingen. Het betreft voornamelijk opleidingen op VMBO-niveau. De wijziging van de opleidingsnamen is doorgevoerd om een betere aansluiting bij de recente ontwikkelingen in het onderwijsveld (invoering WEB en invoering $\mathrm{VMBO}$ ) ${ }^{4}$ te bewerkstelligen. Appendix $\mathrm{B}$ bevat een overzicht van de wijzigingen in de opleidingsnamen.

Voor de arbeidsmarktinformatie naar beroep is gebruik gemaakt van de Standaard Beroepenclassificatie 1992 (SBC '92) van het CBS. Hierdoor wordt de vergelijkbaarheid met andere informatiebronnen over de arbeidsmarkt sterk vergroot. Omdat het CBS de beroepsgroepen aanduidt met vrij abstracte termen, heeft het ROA wel andere benamingen voor deze beroepsgroepen gehanteerd. Uitgangspunt hierbij is dat de namen kort en herkenbaar moeten zijn, en daarnaast een zo groot mogelijk deel van de onderliggende beroepen, gemeten in het aantal werkzame personen, gerepresenteerd moet worden. Op een aantal punten is de CBS-classificatie verder verbijzonderd. De door het CBS onderscheiden elementaire beroepen zijn opgesplitst in zes beroepsgroepen. Ook de beroepsgroep 471 middelbare procestechnische beroepen was dermate heterogeen dat deze is opgesplitst in 471a procesoperators en 471b bakkers en slagers. In De arbeidsmarkt naar opleiding en beroep tot 2004 werden reeds een tweetal beroepsgroepnamen gewijzigd. In appendix $B$ zijn deze wijzigingen vermeld. Overigens worden in de ROA-classificatiegids 2002 (ROA, 2002a) uitgebreide overzichten gegeven van de namen en coderingen van de sectoren, beroepen en opleidingen die binnen POA gehanteerd worden en de koppelingen tussen de classificaties naar opleiding, beroep en sector van het CBS en het ROA.

3. Sinds kort staat het CBS het toe om ook gegevens te publiceren die gebaseerd zijn op een randtotaal van 30.000 werkenden voor één jaar en 15.000 werkenden voor het gemiddelde van twee jaren.

4. Zie voor een toelichting op de opleidingbenamingen in de WEB Bijlage B in De arbeidsmarkt naar opleiding en beroep tot 2004 (ROA, 1999a). 


\section{De actuele situatie op de arbeidsmarkt}

\subsection{Inleiding}

In dit hoofdstuk wordt een overzicht gegeven van de gegevens in het informatiesysteem met betrekking tot de actuele arbeidsmarktpositie vanuit de invalshoek van bedrijfssectoren, beroepsgroepen en opleidingstypen. De gegevens die betrekking hebben op de gehele werkzame beroepsbevolking zijn gebaseerd op de Enquête BeroepsBevolking (EBB) van het CBS. De gegevens hebben betrekking op het gemiddelde aantal werkenden in de jaren 2000 en 2001. Naast de informatie over de actuele arbeidsmarktpositie van de werkzame beroepsbevolking naar opleiding, wordt er aanvullende informatie gegeven over de positie van schoolverlaters. Deze schoolverlatersinformatie is gebaseerd op de schoolverlatersenquêtes RUBS, de HBO-Monitor en de WO-Monitor, welke geïntegreerd zijn in het SchoolverlatersInformatieSysteem (SIS) van het ROA. Voor het AVO, VBO en MBO is gebruik gemaakt van RUBS 2001, terwijl de gegevens over het HBO en het WO gebaseerd zijn op respectievelijk de HBO-Monitor 2001 en WO-Monitor 2001 (zie ook ROA, 2002b). In deze schoolverlatersenquêtes zijn in het najaar van 2001 over de volle breedte van het onderwijsstelsel schoolverlaters en afgestudeerden geënquêteerd ongeveer anderhalf jaar na het voltooien van hun opleiding (schooljaar 1999/2000).

Naast de in hoofdstuk 2 genoemde kwalitatieve typering van de verschillende cijfers, wordt voor de actuele data in de meeste gevallen ook de ontwikkeling (trend) van de desbetreffende cijfers getypeerd, variërend van sterk dalend tot sterk stijgend. Alvorens in te gaan op de actuele data (paragraaf 3.3) die gepresenteerd zijn in De arbeidsmarkt naar opleiding en beroep tot 2006 en het bijbehorende arbeidsmarktinformatiesysteem, wordt in paragraaf 3.2 ingegaan op de bepaling van deze trends.

\subsection{De berekening van de trend}

Uitgangspunt van de methodiek om de trend vast te stellen is een exponentieel model dat wordt geschat en waarin de ontwikkeling van $x_{t}$ wordt verklaard uit een constante term $\alpha$ en een trendvariabele $t, t=1, \ldots, n$ :

$\ln \left(x_{t}\right)=\alpha+\beta t$

De OLS-schatting voor $\beta$ vormt de trend-indicator. Omdat de (natuurlijke) logaritme van de te verklaren variabele is genomen in de vergelijking kan deze indicator geïnterpreteerd worden als de jaarlijkse procentuele groei. De expliciete vergelijking maakt het mogelijk deze trend ook te berekenen voor tijdreeksen met een ontbrekende waarneming. De interpretatie van de indicator is onafhankelijk van de gehanteerde reeks. Wel blijken korte tijdreeksen over het algemeen sterkere trends te vertonen dan langere reeksen. Bij de langere reeksen vallen tegengestelde bewegingen immers tegen elkaar weg. 
Op basis van een analyse van de trends is vastgesteld dat een trendberekening op basis van een vijfjarige tijdreeks het meest geschikt is. Bij het bepalen van de trends is derhalve uitgegaan van de ontwikkelingen in de jaren 1997-2001.

De OLS-schatter voor $\beta$ is voor een reeks van vijf jaren de facto gelijk aan:

$$
\hat{\beta}=-\frac{1}{2} \ln \left(x_{1}\right)-\frac{1}{10} \ln \left(x_{2}\right)+\frac{1}{10} \ln \left(x_{4}\right)+\frac{2}{10} \ln \left(x_{5}\right)
$$

Naast de trendschatting zelf is ook de standaarddeviatie van de geschatte trend berekend. Tijdreeksen met een grillig verloop kunnen per toeval een zeer sterke trendwaarde opleveren. De trend wordt daarom niet meer gepresenteerd als de standaarddeviatie (sd) te groot is:

$$
\left|\frac{\text { trend }}{s d}\right|<1
$$

Evenals de actuele data, de structurele gegevens en de prognoses zijn ook de trendmatige ontwikkelingen kwalitatief getypeerd. Voor elke variabele is dezelfde indeling gehanteerd.

$$
\begin{array}{rlll} 
& \text { trend } \leq-0,10 & \text { sterk dalend } \\
-0,10< & \text { trend } \leq-0,03 & \text { dalend } \\
-0,03< & \text { trend } \leq 0,03 & \text { constant } \\
0,03< & \text { trend } \leq 0,10 & \text { stijgend } \\
0,10< & \text { trend } & & \text { sterk stijgend }
\end{array}
$$

De trendwaarden kunnen rechtstreeks geïnterpreteerd worden als gemiddelde jaarlijkse groei. Overigens dient opgemerkt te worden dat de trend betrekking kan hebben op zowel de absolute waarde, als de relatieve omvang van een variabele; dat wil zeggen: als aandeel in de totale werkzame beroepsbevolking. In de volgende paragrafen zal bij iedere variabele worden aangegeven welke invalshoek is gehanteerd bij het vaststellen van de trend.

\subsection{Toelichting op de variabelen voor de actuele situatie}

In deze paragraaf wordt een technische toelichting gegeven op de variabelen die in het informatiesysteem van het Project Onderwijs-Arbeidsmarkt (POA) zijn opgenomen voor een beschrijving van de actuele situatie op de arbeidsmarkt. ${ }^{5}$ In tabel 3.1 zijn de definities van de variabelen weergegeven. Daarnaast wordt in de tabel aangegeven op welke indeling deze variabele betrekking heeft, i.e. naar bedrijfssector, beroepsgroep of opleidingstype, en uit welke bron de gegevens afkomstig zijn. Deze bron kan betrekking hebben op zowel de

5. Zie paragraaf 5 voor een toelichting op de variabelen die betrekking hebben op de structurele arbeidsmarktsituatie, i.e. de conjunctuurgevoeligheid, de uitwijk- en substitutiemogelijkheden en de concurrentie-index. 
Enquête Beroepsbevolking (EBB) van het CBS als het SchoolverlatersInformatieSysteem (SIS) van het ROA. Voor de variabelen waarvoor een trend is vastgesteld, wordt aangegeven of de trend gebaseerd is op de ontwikkeling van de absolute aantallen werkzame personen of het werkgelegenheidsaandeel.

Tabel 3.1

Technische toelichting op de variabelen over de actuele situatie op de arbeidsmarkt

\section{Aantal werkenden}

beschikbaar voor

bron

trend

\section{Arbeidsvolume}

beschikbaar

bron

trend

\section{Arbeidsmarktpositie potentiële beroepsbevolking}

beschikbaar

bron

trend

\section{Participatie schoolverlaters in vervolgopleidingen}

beschikbaar

bron

trend

Percentage schoolverlaters met een intredewerkloosheid van 4 maanden of langer

beschikbaar

bron

trend
Het aantal werkenden heeft betrekking op iedereen die jonger is dan 65 en minstens 12 uur per week werkt.

bedrijfssector, beroepsgroep, opleidingstype

EBB

ja, absolute aantallen werkenden

Arbeidsvolume is het totaal aantal normaal gewerkte arbeidsuren gedeeld door 40

bedrijfssector, beroepsgroep, opleidingstype

EBB

nee

De potentiële beroepsbevolking betreft alle mensen die ouder zijn dan 15 en jonger dan 64, uitgezonderd studenten/ scholieren in het regulier onderwijs. Het percentage werkloos is de werkloze beroepsbevolking als percentage van de potentiële beroepsbevolking, hetgeen niet verward moet worden met het gebruikelijke werkloosheidspercentage waarin de werkloosheid gerelateerd wordt aan de beroepsbevolking.

opleidingstype

EBB

nee

In de Wet Educatie en Beroepsonderwijs (WEB) waarin de nieuwe kwalificatiestructuur voor het MBO is vastgelegd, wordt onderscheid gemaakt tussen de beroepsopleidende en beroepsbegeleidende leerweg $(B B L)$. Deze laatste is vergelijkbaar met het oude leerlingwezen.

opleidingstype

SIS

nee

Het percentage is gemeten in procenten van de schoolverlaters die tot de beroepsbevolking behoren. Onder intredewerkloosheid wordt het totaal aantal maanden verstaan dat schoolverlaters sinds het verlaten van de opleiding als werkloos hebben opgegeven.

opleidingstype

SIS

nee 
Tabel 3.1 (vervolg)

Technische toelichting op de variabelen over de actuele situatie op de arbeidsmarkt

\section{Percentage werkloze schoolverlaters}

beschikbaar

bron

trend

Percentage vrouwen

beschikbaar

bron

trend

Percentage allochtonen naar etniciteit

beschikbaar

bron

trend

Percentage allochtonen naar herkomst

beschikbaar

bron

trend

Percentage jongeren en ouderen

beschikbaar

bron

trend

\section{Gemiddelde leeftijd}

beschikbaar

bron

trend
Het percentage is gemeten in procenten van de schoolverlaters die tot de beroepsbevolking behoren. De definities van werkloosheid en beroepsbevolking zijn dezelfde als van het CBS.

opleidingstype

SIS

nee

bedrijfssector, beroepsgroep, opleidingstype

EBB

ja, werkgelegenheidsaandeel

Het percentage allochtonen naar etniciteit heeft betrekking op iedereen die een niet-Nederlandse nationaliteit bezit, of die buiten Nederland is geboren, in één van de landen die genoemd worden in de Wet Stimulering Arbeidsdeelname Minderheden (SAMEN). Deze landen zijn: Turkije, Marokko, Suriname, Aruba, Nederlandse Antillen, voormalig Joegoslavië, of in overige landen in Zuid- of Midden-Amerika, Afrika of Azië, met uitzondering van Japan en voormalig Nederlands-Indië. Molukkers behoren wel tot de doelgroep. Op grond van deze wet worden ook kinderen van allochtonen tot de doelgroep gerekend, ongeacht of zij een niet-Nederlandse nationaliteit bezitten. Deze worden in de berekening van het percentage allochtonen naar etniciteit echter niet meegenomen.

bedrijfssector, beroepsgroep, opleidingstype

EBB

ja, werkgelegenheidsaandeel

Het percentage allochtonen naar herkomst heeft betrekking op iedereen waarvan ten minste één ouder in het buitenland is geboren. Het buitenland is daarbij op te splitsen in westerse en niet-westerse herkomstlanden. Het percentage allochtonen naar herkomst heeft betrekking op niet-westerse herkomstlanden. Tot de niet-westerse herkomstlanden worden gerekend Turkije en alle landen in Afrika, Latijns-Amerika en Azië (met uitzondering van Japan en Indonesië).

bedrijfssector, beroepsgroep, opleidingstype

EBB

nee, te weinig jaren om een trend te bepalen

De jongeren betreft alle mensen die ouder dan 15 jaar en jonger dan 30 jaar zijn. Voor de ouderen geldt dat ze ouder dan 50 jaar en jonger dan 64 jaar zijn.

bedrijfssector, beroepsgroep, opleidingstype

EBB

ja, werkgelegenheidsaandeel

beroepsgroep, opleidingstype

EBB

nee 
Tabel 3.1 (vervolg)

Technische toelichting op de variabelen over de actuele situatie op de arbeidsmarkt

Percentage deeltijdarbeid Deeltijdarbeid betreft personen die hoogstens 32 uur maar minstens 12 uur per week werkzaam zijn.

beschikbaar bedrijfssector, beroepsgroep, opleidingstype

bron EBB

trend ja, werkgelegenheidsaandeel

Percentage deeltijdarbeid Deeltijdarbeid betreft de schoolverlaters die hoogstens 32 uur maar onder schoolverlaters minstens 12 uur per week werkzaam zijn.

beschikbaar

opleidingstype

bron SIS

trend nee

\author{
Gemiddeld aantal uren \\ per week \\ beschikbaar bedrijfssector, beroepsgroep, opleidingstype \\ bron EBB \\ trend nee
}

Percentage flexibel werk Van een flexibele arbeidsrelatie is sprake bij uitzendkrachten, oproepkrachten, invalskrachten en contracten zonder een vast aantal arbeidsuren en indien geen vast dienstverband is overeengekomen. Een arbeidscontract wordt als niet-vast beschouwd als de contractuele termijn korter is dan een jaar en er geen vooruitzicht is op een vast dienstverband.

beschikbaar bedrijfssector, beroepsgroep, opleidingstype

bron EBB

trend ja, werkgelegenheidsaandeel

Percentage vast werk

beschikbaar

bron

bedrijfssector, beroepsgroep, opleidingstype

trend

EBB

ja, werkgelegenheidsaandeel

Percentage werkzame

schoolverlaters met vast

dienstverband

beschikbaar

opleidingstype

bron

SIS

trend

nee

Percentage zelfstandigen Het begrip zelfstandig bevat ook personen die werkzaam zijn in het bedrijf of de praktijk van hun partner of ouders en freelancers e.d.

beschikbaar

bedrijfssector, beroepsgroep, opleidingstype

bron

EBB

trend ja, werkgelegenheidsaandeel 
Tabel 3.1 (vervolg)

Technische toelichting op de variabelen over de actuele situatie op de arbeidsmarkt

Gemiddeld bruto maand- Dit bruto maandloon is samengesteld op basis van een voltijdaanstelling. loon van werkzame schoolverlaters

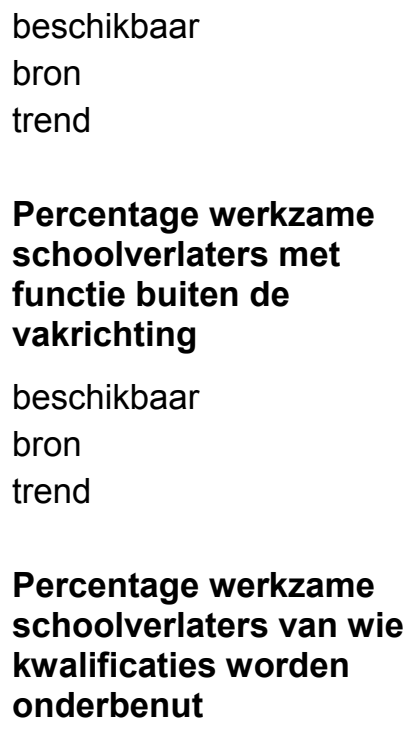

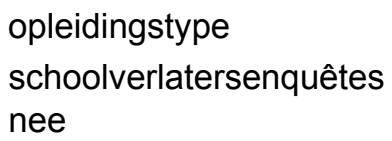

De functie is een functie buiten de eigen vakrichting wanneer voor de functie de eigen of een verwante opleidingsrichting niet vereist is.

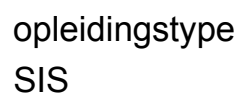

Onderbenutting wordt bepaald op basis van het opleidingsniveau dat vereist is voor de functie.

opleidingstype

SIS

nee

Hierin zijn alle beroepsgroepen opgenomen die ten minste betrekking hebben op $5 \%$ van de totale werkgelegenheid in de desbetreffende bedrijfssector/opleidingstype.

bedrijfssector, opleidingstype

EBB

ja, werkgelegenheidsaandeel

Hierin zijn alle bedrijfssectoren opgenomen die ten minste betrekking hebben op $5 \%$ van de totale werkgelegenheid in de desbetreffende beroepsgroep/opleidingstype.

beroepsgroep, opleidingstype

\section{EBB}

ja, werkgelegenheidsaandeel

Hierin zijn alle opleidingstypen opgenomen die ten minste betrekking hebben op $5 \%$ van de totale werkgelegenheid in de desbetreffende bedrijfssector/beroepsgroep.

bedrijfssector, beroepsgroep

EBB

ja, werkgelegenheidsaandeel 


\section{Methodiek arbeidsmarktprognoses}

\subsection{Inleiding}

In dit hoofdstuk wordt ingegaan op de gehanteerde onderzoeksmethoden van de middellangetermijnprognoses naar beroepsgroep en opleidingstype voor de periode 20012006. In de inleiding 'Doel en opzet van de arbeidsmarktprognoses' van De arbeidsmarkt naar opleiding en beroep tot 2006 wordt een globaal overzicht gegeven van het prognosemodel van het informatiesysteem. Dit algehele overzicht zal hier niet worden herhaald, maar aansluitend daarop zal meer specifiek op de verschillende prognoseonderdelen worden ingegaan. Achtereenvolgens zal de methodiek van de uitbreidingsvraagprognose (paragraaf 4.2), de prognose van de vervangingsvraag (paragraaf 4.3) en de prognose van de toekomstige instroom van nieuwkomers op de arbeidsmarkt (paragraaf 4.4) worden besproken. Ten slotte wordt een toelichting gegeven op de totstandkoming van de samenvattende indicatoren van aan de ene kant de arbeidsmarktperspectieven per opleidingstype en aan de andere kant de verwachte knelpunten in de personeelsvoorziening per opleidingstype en per beroepsgroep.

\subsection{Methodiek uitbreidingsvraag}

Op basis van het Athena-model (CPB, 1990) maakt het CPB prognoses van de werkgelegenheidsontwikkeling per bedrijfstak. Deze werkgelegenheidsprognoses vormen het startpunt van de prognoses van de uitbreidingsvraag naar beroepsgroep en opleidingstype.

De in dit rapport gepresenteerde prognoses van de werkgelegenheidsontwikkeling voor de periode 2001-2006 zijn gebaseerd op de korte termijnprognoses tot en met 2002 uit het Centraal Economisch Plan $2001^{6}$ en het Global Competition scenario uit Omgevingsscenario's Lange Termijn Verkenning 1995-2020 van het CPB. ${ }^{7}$ Hierbij is 1999 als basisjaar genomen in verband met de late beschikbaarheid van de EBB 2000, waardoor de feitelijke prognoseperiode 2000-2006 is. De procentuele ontwikkelingen en de prognoses van het aantal werkenden in het informatiesysteem zijn echter altijd weergegeven ten opzichte van het basisjaar 2000, waarbij derhalve een schatting moest worden gemaakt van het aantal werkenden per bedrijfssector, beroepsgroep of opleidingstype in 2000.

In figuur 4.1 staat aangegeven hoe de prognoses van de werkgelegenheidsontwikkeling voor beroepen en opleidingen tot stand komen. Vanuit de bedrijfssectorprognoses wordt een prognose opgesteld voor beroepssegmenten. Vervolgens vindt er vanuit de werkgelegenheidsprognoses per beroepssegment een verdere uitsplitsing plaats naar de beroepsgroepen.

\footnotetext{
6. Zie CPB (2001).
}

7. Zie CPB (1997). 
Figuur 4.1

Overzicht van de totstandkoming van de prognoses naar beroepsgroep en opleidingstype

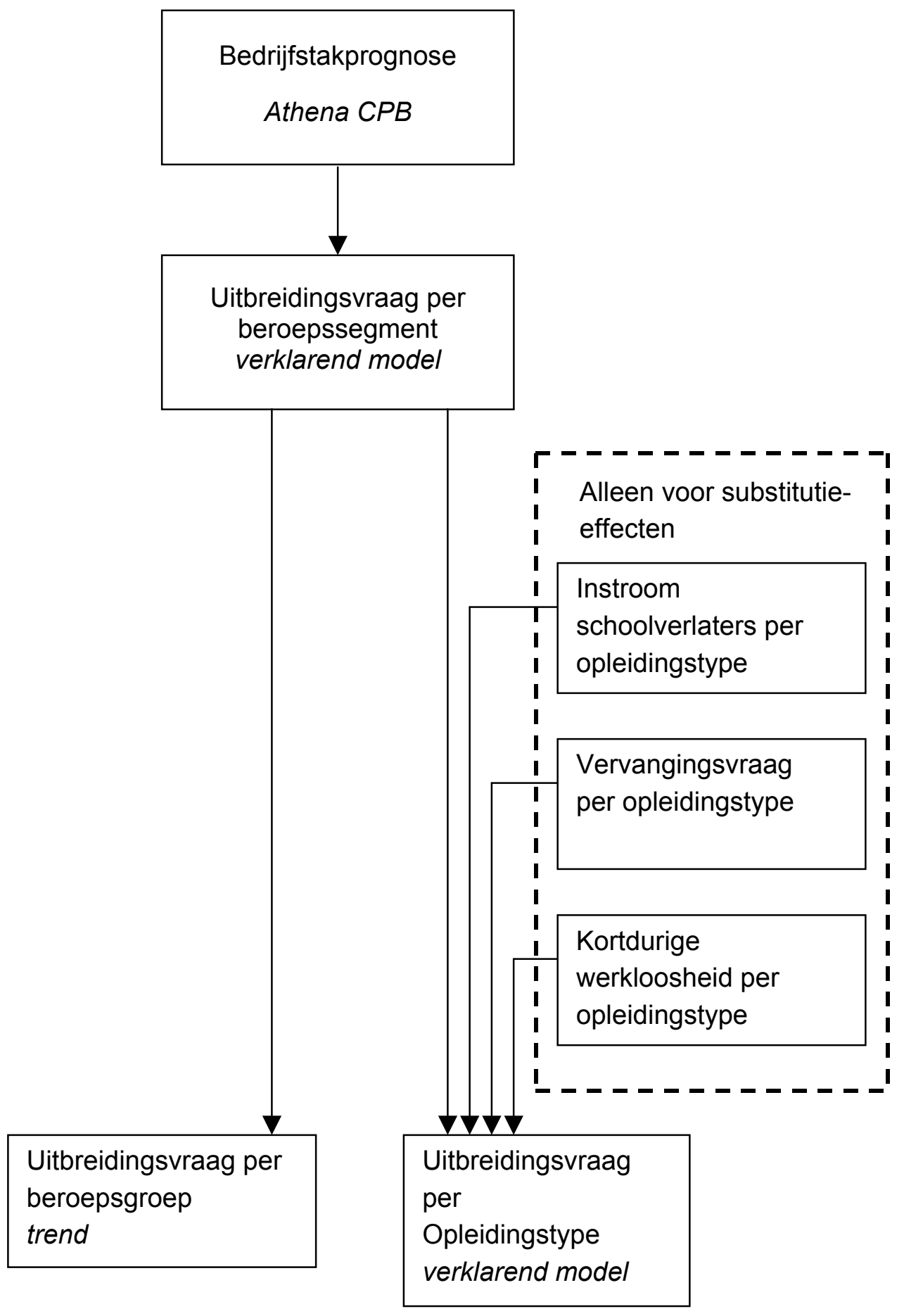

De beroepenindeling is gebaseerd op de Standaard Beroepen Classificatie uit 1992 (SBC '92) van het CBS (1993). De beroepssegmenten zijn gebaseerd op de indeling op 2-digit- 
niveau; de beroepsgroepen op de indeling op 3-digit-niveau. ${ }^{8} \mathrm{Er}$ worden in totaal 43 beroepssegmenten en 127 beroepsgroepen onderscheiden. ${ }^{9}$

De prognoses van de werkgelegenheidsontwikkelingen per beroepssegment vormen de basis voor de prognoses van de uitbreidingsvraag per opleidingstype. In het opleidingenmodel vindt een confrontatie plaats tussen vraag en aanbod, waardoor ook de invloeden op de vraag die veroorzaakt worden door overschotten of tekorten in aanverwante studierichtingen in het model konden worden opgenomen. Hiervoor zijn de prognoses van de arbeidsmarktinstroom van schoolverlaters en de vervangingsvraag en de informatie over de kortdurige werkloosheid per opleidingstype aan het begin van de prognoseperiode noodzakelijke invoergegevens voor het model.

\section{Het beroepenmodel}

Bij het beroepenmodel wordt de voorspelde werkgelegenheidsontwikkeling per bedrijfstak omgezet naar de werkgelegenheidsontwikkeling per beroepssegment en beroepsgroep. Hierbij wordt de veronderstelling gemaakt dat de werkgelegenheid per beroepsgroep volledig door de vraagzijde van de markt bepaald wordt. De ontwikkelingen in de vraag per beroepsgroep worden bepaald door de werkgelegenheidsverschuivingen tussen bedrijfstakken en de veranderingen in de beroepenstructuur van de werkgelegenheid per bedrijfstak.

De ontwikkelingen van de werkgelegenheidsstructuur naar beroep zijn geschat op basis van de EBB-data van 1988 tot en met 1999. Het gaat bij deze werkgelegenheidscijfers om werkzame personen die een werkverband van minstens 12 uren per week hebben. Voor de prognoses van de werkgelegenheid naar opleiding zouden wegingsproblemen met de EBBdata voor 1998 een probleem kunnen betekenen. Daarom zijn deze voor de ontwikkelingen van de werkgelegenheidsstructuur naar opleiding niet gebruikt. In plaats daarvan zijn de schattingen van Borghans (1996) van trendmatige verschuivingen in de opleidingsstructuur gecombineerd met het model van Marey (2001) voor de snelheid waarin deze trendmatige ontwikkelingen zich voltrekken, waardoor de actuele economische ontwikkelingen alsnog kunnen worden gebruikt bij het maken van prognoses, zonder gebruik te maken van de EBB 1998.

Het CBS is vanaf 1994 over gegaan op een nieuwe bedrijfssectorindeling. Om toch de EBB gegevens voor de periode 1988 tot en met 1993 te kunnen gebruiken is een schatting gemaakt van aantallen werkenden per bedrijfssector volgens de nieuwe indeling. Dit was mogelijk omdat in 1994 zowel de oude als de nieuwe classificatie gehanteerd zijn. De

8. Bij de beroepsgroepindeling zijn, zoals reeds eerder is opgemerkt, de elementaire beroepen opgesplitst in zes beroepsgroepen, terwijl de middelbare procestechnische beroepen (code 471) verder zijn opgesplitst in de beroepsgroepen procesoperators en bakkers en slagers.

9. Zie de 2-digitcodes en bijbehorende benamingen in de ROA-classificatiegids (ROA, 2002, tabel 6 en 7 ). 
verhoudingen van de aantallen werkenden per beroepssegment per bedrijfssector volgens de oude en nieuwe indeling in dat jaar zijn dus bekend.

Om stabiele parameterschattingen te krijgen zonder daarbij de specificiteit van de afzonderlijke beroepen aan te tasten is gebruik gemaakt van een random-coëfficiëntenmodel. ${ }^{10}$ In dit random-coëfficiënten-model worden de parameterwaarden bepaald als een gewogen gemiddelde van aan de ene kant een gemiddelde parameterwaarde over alle beroepen waarover gepoold wordt, en aan de andere kant schattingen voor de afzonderlijke beroepen. Het gewicht wordt bepaald door de nauwkeurigheid van beide onderdelen. Als er veel variatie is tussen de verschillende beroepen is een gepoolde schatting relatief onnauwkeurig en komt er meer gewicht op de afzonderlijke schattingen te liggen. Als deze afzonderlijke schattingen echter een hoge standaardfout hebben wordt hun gewicht verlaagd. Op deze wijze ontstaat er een optimale combinatie van de informatie van de gepoolde gegevens en de afzonderlijke schattingen.

Per bedrijfssector is de volgende specificatie als uitgangspunt genomen:

$$
\Delta a_{t}^{b s}=\Delta a_{t}^{s}+\beta_{0}^{b s}+\beta_{1}^{b s}\left(\Delta a_{t-1}^{b s}-\Delta a_{t-1}^{s}\right)+\beta_{2}^{b s} \dot{Y}_{t}^{s}+\beta_{3}^{b s} U \dot{U} R_{t}^{s}+\beta_{4}^{b s} W \dot{L} H_{t}+\varepsilon_{t}^{b s}
$$

waarbij:

$a_{t}^{b s}=$ de logaritme van het aantal werkzame personen in beroep $b$ in bedrijfssector $s$ op tijdstip $t$.

$a_{t}^{s}=$ de logaritme van het totale aantal werkzame personen in bedrijfssector $s$ op tijdstip $t$.

Verondersteld wordt dat de vector $\beta^{b s}=\left(\beta_{0}^{b s}, \ldots, \beta_{4}^{b s}\right)$ normaal verdeeld is:

$\beta^{b s} \sim N\left(0, \Sigma^{s}\right)$

ledere parameter is dus specifiek voor elk beroep $(b)$ in iedere bedrijfssector $(s)$, maar vanwege de random-coëfficiënten structuur is er een onderlinge band tussen de parameters van de verschillende beroepen in dezelfde bedrijfssector.

De verklarende variabelen die gebruikt zijn in (4.1) zijn de volgende:

- $\dot{Y}$ : De groei in de productiecapaciteit. Bij de industriële bedrijfssectoren is deze telkens bepaald door het aantal arbeidsjaren bij een volledige bezetting te berekenen (dat is de huidige werkgelegenheid gedeeld door de bezettingsgraad).

- UÜR: De relatieve verandering van de contractueel gewerkte uren per jaar.

- WLH: De relatieve verandering van het werkloosheidspercentage.

Deze verklarende variabelen komen overeen met de variabelen in de werkgelegenheidsvergelijkingen van het Athena-model. Als verondersteld wordt dat de variabelen die de totale

10. Borghans en Heijke (1994) geven een uitvoerige beschrijving van dit model. 
werkgelegenheid in een bedrijfssector bepalen, niet op alle beroepssegmenten dezelfde invloed hebben, dan zijn deze variabelen ook van invloed op de afwijking tussen de werkgelegenheidsontwikkeling van de bedrijfssector als geheel en de werkgelegenheidsontwikkeling in het specifieke beroepssegment. Omdat het model geschat moest worden op basis van slechts 9 observaties was het aantal vrijheidsgraden zo laag dat dit tot zeer onbetrouwbare en implausibele schattingen zou kunnen leiden. Er is daarom voor gekozen om niet alle verklarende variabelen in het model op te nemen. De groei van het aantal contractuele uren is uiteindelijk voor geen van de bedrijfssectoren meer opgenomen. Tabel 4.1 geeft aan welke verklarende variabelen per bedrijfssector zijn opgenomen.

De arbeidsvolume-prognoses van het CPB zijn met behulp van de P/A-ratio's van het CPB omgerekend naar werkzame personen. De cijfers van het CPB, die gebaseerd zijn op de Nationale Rekeningen, komen echter niet volledig overeen met de cijfers uit de EBB. Om deze cijfers onderling vergelijkbaar te maken zijn de CPB-prognoses vermenigvuldigd met een factor, zodanig dat de beide cijferreeksen in 1999 aan elkaar gelijk zijn.

Tabel 4.1

Overzicht van de verklarende variabelen per bedrijfssector

\begin{tabular}{lcc}
\hline Bedrifssector & \multicolumn{3}{c}{ gebruikte verklarende variabelen } \\
& constante & $\dot{Y}$ \\
& & WLH \\
Landbouw, visserij en bosbouw & $\mathrm{x}$ & $\mathrm{x}$ \\
Voedings- en genotmiddelenindustrie & $\mathrm{x}$ & $\mathrm{x}$ \\
Chemie & $\mathrm{x}$ & $\mathrm{x}$ \\
Metaal, elektrotechnische en transportmiddelenindustrie & $\mathrm{x}$ & $\mathrm{x}$ \\
Overige industrie & $\mathrm{x}$ & \\
Energie & $\mathrm{x}$ & \\
Bouw & $\mathrm{x}$ & \\
Handel & $\mathrm{x}$ & \\
Vervoer en communicatie & $\mathrm{x}$ & \\
Overige commerciële dienstverlening & $\mathrm{x}$ & \\
Kwartaire diensten & $\mathrm{x}$ & \\
Openbaar bestuur, politie, defensie en onderwijs & $\mathrm{x}$ \\
\hline
\end{tabular}

Verder zijn in de EBB-matrices beroepssegment $\mathrm{x}$ bedrijfssector de aantallen beneden de CBS-ondergrens gelijkgesteld aan 0 . Hierdoor verdwijnen in iedere bedrijfssector een aantal kleinere beroepen. Beroepen die voor één of meerdere jaren niet voorkomen in de tijdreeks zijn weggelaten. Er ontstaat door het ontbreken van informatie met betrekking tot deze lage aantallen een discrepantie tussen de aantallen werkzame personen per beroepssegment en het totaal per bedrijfssector. Hiervoor is een extra beroepssegment 'overige' geïntroduceerd, waarin per bedrijfssector alle werkzame personen worden samengenomen die niet in een bepaalde beroep zijn geregistreerd. Voor deze extra categorie zijn ook prognoses gemaakt. Uiteraard bestaat er ook een discrepantie tussen het totaal aantal werkenden per beroepssegment en de som van de beroepenaantallen per bedrijfssector. Deze discrepantie is gelijk aan de som van de discrepanties binnen de bedrijfssectoren. In het model worden ook prognoses gemaakt voor deze beroepsaandelen waarvan de bedrijfssector niet bekend is vanwege de gehanteerde ondergrens. Hiertoe wordt een sector 'overige' geïntroduceerd. De 
groei van de werkzame personen in deze sector 'overige' wordt geschat in afwijking van de ontwikkeling van het beroepssegment 'overige'.

Ten slotte is er nog een groep mensen van wie of het beroep of de sector om enige reden niet gecodeerd is. In de periode 1992-1995 heeft het CBS niet het beroep gecodeerd van mensen die een aanstelling hadden van minder dan een half jaar zonder vooruitzicht op verlenging. Omdat dit tot 1992 wel gebeurde en vanaf 1996 ook weer neemt het aantal mensen van wie het beroep niet gecodeerd is van 1991 op 1992 sterk toe en van 1995 op 1996 weer sterk af. Deze breuk in de data wordt opgevangen door een dummyvariabele voor 1992 en 1996 aan vergelijking (4.1) toe te voegen. Daarbij is verondersteld dat voor elk beroepssegment in een bedrijfssector de proportionele afname van 1991 op 1992 als gevolg van niet coderen gelijk is aan de proportionele toename in 1996. Beroep 'onbekend' wordt verder als een gewoon beroepssegment behandeld. ${ }^{11}$ Voor de werkenden waarvoor om enige reden de sector waarin ze werkzaam zijn niet is gecodeerd is een sector 'onbekend' toegevoegd. ${ }^{12}$ De groei van de werkgelegenheid in deze sector is bepaald als het verschil tussen de totale werkgelegenheidsgroei in aantallen werkzame personen per leeftijdssector volgens het CPB en de totale werkgelegenheidsgroei voorspeld op basis van de aantallen werkzame personen per sector volgens de EBB, exclusief de sector 'onbekend'.

Omdat de hierboven beschreven methode op bepaalde punten tot implausibele resultaten leidde, is deze algemene opzet op een punt ad hoc aangepast. De werkgelegenheidsgroei in de Hogere pedagogische beroepen in de overheidssector is constant verondersteld. Deze aanpassing was ook al noodzakelijk bij de eerdere prognoses.

Vervolgens zijn de prognoses per beroepssegment verbijzonderd naar beroepsgroepen. Ook hierbij is gebruik gemaakt van het random-coëfficiënten-model. De werkgelegenheidsgroei per beroepsgroep wordt daarbij geschat als afwijking van de totale groei van het beroepssegment waar de betreffende beroepsgroep onder valt.

$$
\Delta a_{t}^{g}=\Delta a_{t}^{b}+\beta_{0}^{g}+\beta_{1}^{g}\left(\Delta a_{t-1}^{g}-\Delta a_{t-1}^{b}\right)+\varepsilon_{t}
$$

Waarbij:

$a_{t}^{g}=$ logaritme van het aantal werkzame personen in beroepsgroep $g$ op tijdstip $t$

$a_{t}^{b}=$ logaritme van het totaal aantal werkzame personen in beroepssegment $b$ waartoe beroepsgroep $g$ wordt gerekend op tijdstip $t$

Overigens is ook bij de schattingen van dit model een dummy-variabele voor 1992 en 1996 opgenomen. Ook hier hebben een aantal ad hoc aanpassingen plaatsgevonden. Het betreft

11. Bij beroepssegment 'onbekend' gaat het dus om mensen van wie het beroep niet gecodeerd is, terwijl het bij het beroepssegment 'overige' gaat om mensen van wie het beroep wel gecodeerd is maar niet bekend is vanwege de genoemde ondergrenzen.

12. Hier geldt hetzelfde onderscheid tussen de sector 'overige' en de sector 'onbekend' als bij de beroepssegmenten. 
voornamelijk gevallen waarin de voorspelde groei van een enkele beroepsgroep zo groot was dat de groei van de andere beroepsgroepen die onder hetzelfde beroepssegment vallen, vanwege het verdeelkarakter van het model, onwaarschijnlijk laag werd. In deze gevallen is voor de betreffende beroepsgroepen de werkgelegenheidsgroei gelijk verondersteld aan de werkgelegenheidstoename van het beroepssegment of zijn de parameters in het model op 0 gezet. Het gaat hier om de beroepsgroepen docenten talen en expressie, onderwijskundigen en pedagogen, architecten en bouwkundig projectleiders, accountants, organisatiedeskundigen, politieagenten, onderofficieren en beveiligingsemployés en politieinspecteurs en onderofficieren.

\section{Het opleidingenmodel}

Bij de prognoses die in 1993 werden opgesteld is voor het eerst expliciet een onderscheid gemaakt tussen de 'vraag' en de 'werkgelegenheid' per opleidingstype. Onder vraag wordt verstaan de hoeveelheid werk die wordt aangeboden als de verhoudingen op de arbeidsmarkt zich niet zouden wijzigen. Als er echter voor een bepaalde opleidingsrichting discrepanties ontstaan tussen de vraag- en aanbodontwikkeling, zullen er in de praktijk veelal aanpassingsprocessen ontstaan. Zo leidt een overschot aan de aanbodkant er mogelijk toe dat schoolverlaters banen krijgen waarin ze voorheen niet werkzaam waren. De uiteindelijke hoeveelheid werk wordt aangeduid als werkgelegenheid. Er ontstaat derhalve een verschil tussen het ex ante vraagbegrip en de ex post werkgelegenheid.

Om de te verwachten spanning tussen vraag en aanbod in kaart te brengen is de ex ante vraag het meest geschikt. De aanpassingen die achteraf plaatsvinden zijn immers al een uiting van deze spanningen tussen vraag en aanbod. In de data wordt echter de ex post vraag waargenomen. Door in het opleidingenmodel de historische vraag te baseren op deze feitelijke werkgelegenheid worden mogelijk vraag- en aanbodelementen samengenomen. Wanneer in het verleden een toename in de werkgelegenheid het gevolg was van een vergroot aanbod kan dit geïnterpreteerd worden als een toename van de ex ante vraag, waardoor de spanning tussen vraag en aanbod onderschat zal worden. Om deze verwarring tussen vraag- en aanbodelementen te voorkomen is door Borghans en Heijke (1996) een model ontwikkeld waarin het onderscheid tussen ex ante en ex post vraag naar arbeid expliciet is opgenomen. In dit model wordt, om deze twee afzonderlijke categorieën te kunnen identificeren, rekening gehouden met de onderlinge substitutie tussen opleidingstypen. In Borghans (1996) is dit model verder uitgewerkt.

In figuur 4.2 wordt de opbouw van het model getoond. De ex ante vraag per opleidingstype (o) per beroepssegment $b$ wordt bepaald door de verdeling van de opleidingstypen in dit beroepssegment in het laatste observatiejaar. Op basis van het model van Borghans (1996) wordt geschat in welke mate de vraag naar een bepaald opleidingstype toe- of afneemt als gevolg van trendmatige verschuivingen. Deze veranderingen in de vraag weerspiegelen upen downgradingsprocessen in de werkgelegenheidsstructuur.

Vervolgens is aan de hand van het model van Marey (2001) een prognose gemaakt voor het tempo waarin deze trends zich naar verwachting zullen voortzetten. Op basis van het Global 
Competition scenario zijn veronderstellingen gemaakt omtrent de toekomstige ontwikkeling in de R\&D- en ICT-uitgaven. Historisch gezien zijn R\&D-uitgaven aanmerkelijk meer variabel dan ICT-uitgaven en vormen derhalve de belangrijkste oorzaak van veranderingen in de snelheid van het upgradingsproces. Aangezien het Global Competition scenario gekenmerkt door snelle technologische ontwikkelingen, wordt voor de periode 2000-2006 uitgegaan van een sterke toename in R\&D-uitgaven. Ten aanzien van de ICT-uitgaven wordt uitgegaan van de groeisnelheid in het verleden. Implementatie van deze scenario's voor R\&D- en ICTuitgaven in het recent ontwikkelde model leidt tot een upgradingssnelheid die $12 \%$ hoger ligt dan in de vorige editie van De arbeidsmarkt naar opleiding en beroep (ROA, 1999a).

Figuur 4.2

De opbouw van de vraag naar arbeid per opleidingstype

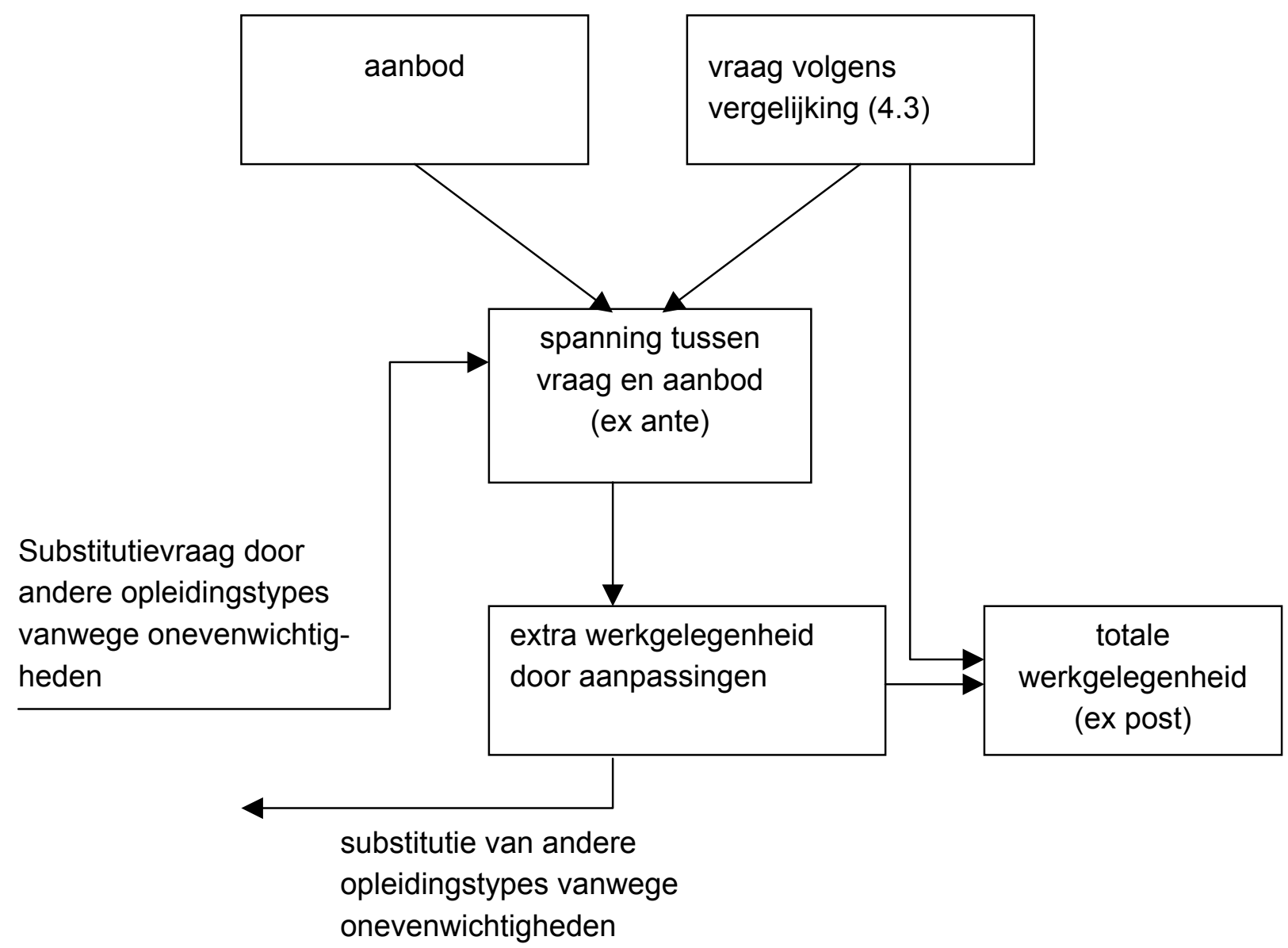

Ten slotte worden deze trendmatige ontwikkelingen gecorrigeerd voor een toe- of afname in de werkgelegenheid die het gevolg is van 'overschotten' of 'tekorten' aan mensen met een bepaalde opleidingsachtergrond. Als de vraag groter is dan het aanbod voor een bepaald opleidingstype zal immers de uiteindelijke werkgelegenheid zoals die wordt waargenomen kleiner zijn dan de oorspronkelijke vraag. Omgekeerd zal bij een aanbodoverschot de uiteindelijke werkgelegenheid juist groter worden vanwege verdringingsprocessen. Borghans en Willems (1998) gaan in op deze relatie tussen vraag en werkgelegenheid. Als het aanbod van een opleidingstype groter is dan de vraag, zal volgens dit model de arbeidsmarktpositie van het opleidingstype verslechteren. De nieuwkomers op de arbeidsmarkt zullen daardoor 
moeten uitwijken naar andere minder aantrekkelijke banen. Deze uitwijk naar andere banen is geschat op basis van de methode in Borghans (1996) Omdat de totale vraag per beroepssegment verondersteld wordt constant te zijn, betekent de instroom van het ene opleidingstype automatisch de verdringing van andere opleidingstypen. Hier wordt verondersteld dat deze uitstroom proportioneel is aan de opleidingsstructuur van dit beroepssegment. Deze verdringing betekent voor de betreffende opleidingstypes echter een vergroting van de discrepantie tussen vraag en aanbod. Door enkele malen een iteratie uit te voeren wordt een evenwichtssituatie gevonden die de ex ante vraag met substitutie aangeeft.

Deze uitbreidingsvraag met substitutie geeft aan hoe groot de vraag naar schoolverlaters met een bepaalde opleidingsachtergrond is, als er geen rekening wordt gehouden met de mate waarin dit opleidingstype zich aanpast aan de arbeidsmarktsituatie (de 'actieve substitutie'), maar waarbij wel rekening is gehouden met de vraagtoename, als gevolg van een vraagoverschot bij een andere verwante opleiding, of een vraagafname vanwege de verdringing door andere opleidingstypen (de 'passieve substitutie'). De reden waarom er geen rekening wordt gehouden met de 'actieve' substitutie is dat deze aanpassingen - in het geval van een aanbodoverschot - op zichzelf reeds een verslechtering zullen betekenen. Door de werkgelegenheid die door het aanpassingsproces op de arbeidsmarkt wordt verkregen in mindering te brengen op het aanbodoverschot zou een verslechterend perspectief onderschat worden. Het verlies aan werkgelegenheid door de aanpassingen van andere opleidingstypen betekent echter een verslechtering van de werkgelegenheid, zodat deze component wel moet worden meegenomen in de ex ante vraag (zie De Grip, Borghans en Smits, 1998).

Ook bij het opleidingenmodel hebben enkele aanpassingen van het basismodel plaatsgevonden. Bij de hogere onderwijskundige beroepen, de middelbare en hogere medische en paramedische beroepen en de hogere theologische beroepen is uitgesloten dat er substitutie plaatsvindt, omdat er in de praktijk scherpe afgrenzingen zijn tussen de vakgebieden van de beroepsgroepen die binnen deze beroepssegmenten worden onderscheiden.

\subsection{Methodiek vervangingsvraag}

Naast de uitbreidingsvraag is ook de vervangingsvraag een belangrijke component van het totaal aantal baanopeningen voor de nieuwkomers op de arbeidsmarkt. Met de vervangingsvraag wordt de vraag naar nieuwkomers bedoeld die ontstaat als gevolg van het verloop vanwege pensionering, VUT, arbeidsongeschiktheid, (tijdelijke) uittreding van met name gehuwde vrouwen, beroepsmobiliteit e.d. (zie ook Willems en De Grip, 1993). Bij een toename van de werkgelegenheid is de vervangingsvraag gelijk aan het aantal werkenden dat hun baan in een bepaalde periode verlaat. De opengevallen arbeidsplaatsen zullen immers eerst moeten worden opgevuld voordat er sprake kan zijn van werkgelegenheidsgroei. Echter, ook bij een dalende werkgelegenheid kan de vraag naar nieuwkomers, uitsluitend als gevolg van de vervangingsvraag, nog aanzienlijk zijn. De vervangingsvraag is dan echter niet gelijk aan de uitstroom, maar alleen aan de uitstroom voor zover deze 
vervangen wordt. Dit impliceert dat bij een krimpende vraag de vervangingsvraag lager zal zijn dan de uitstroom van werkenden.

Overigens dient te worden beseft dat de vervangingsvraag gesommeerd over alle beroepsgroepen niet gelijk is aan de vervangingsvraag gesommeerd over alle opleidingstypen. De beroepsmobiliteit is namelijk wel van invloed op de vervangingsvraag per beroepsgroep, maar heeft geen effect op de vervangingsvraag per opleidingstype. Het veranderen van beroep heeft immers geen gevolgen voor de opleidingsstructuur van de werkgelegenheid. Daarentegen kan een werkende door het afronden van een vervolgopleiding in feite 'uitstromen' naar een ander opleidingstype. In dat geval is er sprake van een vervangingsvraag bij het opleidingstype waartoe de vooropleiding van deze werkende wordt gerekend.

Voor het bepalen van de vervangingsvraag is een model ontwikkeld dat nauw aansluit bij de in demografische analyses vaker gebruikte cohort componenten methode. De cohortcomponenten-methode baseert de berekening van de zogenaamde 'cohort change rates' op het aantal personen in hetzelfde geboortecohort die werkzaam zijn in twee verschillende tijdsperioden. Een cohort is hier een combinatie van geslacht en vijfjaars-leeftijdsklasse. ${ }^{13}$ Deze methode maakt gebruik van standcijfers over de geslachts- en leeftijdsopbouw van de beroepsbeoefenaren over een aantal jaren. ${ }^{14}$ Door van jaar op jaar een vergelijking te maken van de demografische opbouw in een bepaalde beroepsgroep of een bepaald opleidingstype, wordt een beeld verkregen van de (netto) in- of uitstroom voor de desbetreffende beroepsgroep of het desbetreffende opleidingstype. Op dit model zal hier kort worden ingegaan (zie voor een verdere toelichting Willems, 1999).

Kernpunt bij de methodiek voor de bepaling van de vervangingsvraag is de afleiding van de netto in- en uitstroomratio's. Deze ratio's weerspiegelen de relatieve toe- of afname van het aantal werkenden in een beroepsgroep ${ }^{15}$ van een bepaald geboortecohort gedurende een bepaalde periode. In symbolen kunnen de 'cohort change rates' worden weergegeven als: ${ }^{16}$

$$
\dot{F}_{b x}^{t-1}=\frac{W_{b x+1}^{t}-W_{b x}^{t-1}}{W_{b x}^{t-1}}
$$

13. Zie voor een verdere toelichting Shryock en Siegel (1980).

14. Bij het opstellen van de prognoses voor de periode 2001-2006 is gebruik gemaakt van naar geslacht en leeftijdsklasse verbijzonderde gegevens over het aantal werkenden per beroepsgroep en opleidingstype voor de periode 1987-1999, respectievelijk 1992-1999.

15. De methodiek is hier uitgewerkt voor de vervangingsvraag per beroepsgroep. De vervangingsvraag per opleidingstype wordt op vrijwel analoge wijze bepaald.

16. Daarnaast zijn de ratio's verbijzonderd naar geslacht. Omwille van de overzichtelijkheid van de notatie is de geslachtsindex weggelaten. 
waarbij:

$\dot{F}_{b x}^{t-1}=$ netto in- of uitstroomratio van de werkenden in beroep $b$ met leeftijdklasse $x$ op tijdstip $t-1$, gedurende de periode $(t-1, t)$;

$W_{b x}^{t}=$ aantal werkenden in beroep $b$ in leeftijdsklasse $x$ op tijdstip $t$.

Indien $\dot{F}_{b x}^{t-1}>0$ dan is er sprake van netto instroom voor leeftijdscohort $x$ van beroep $b$ en als $\dot{F}_{b x}^{t-1}<0$ dan is er sprake van netto uitstroom. Er wordt dus met behulp van de cohort change rate de netto uitstroom, het saldo van uit- en instroom, in het verleden per beroepsgroep bepaald. De vervangingsvraag die wordt opgevuld door (her-)intredende personen van hetzelfde cohort (combinatie van geslacht én leeftijdsklasse) kan niet uit de beschikbare data worden afgeleid en wordt derhalve ook niet expliciet bij de bepaling van de vervangingsvraag meegenomen. Dit houdt in dat wordt aangenomen dat een meer dan normaal (op basis van het verleden) geacht aantal herintreders in de wachtrij voor nieuwe banen achteraan moet sluiten bij de nieuw op de markt komende schoolverlaters (zie ook Borghans, De Grip en Willems, 1995).

Vervolgens wordt er gebruik gemaakt van een random-coëfficiënten-model, waarbij de netto in- of uitstroomratio's worden verklaard op basis van enerzijds de gemiddelde in- of uitstroompatronen uit de totale werkzame bevolking en anderzijds de beroepsspecifieke afwijkingen per geslacht en leeftijdsklasse. Dit houdt in dat wanneer een geschatte uitstroomcoëfficiënt voor een bepaalde beroepsklasse of opleidingstype te sterk afwijkt, deze wordt vervangen door een meer robuuste uitkomst van een bovenliggende beroepsklasse of opleidingscategorie. Een dergelijke aanpak garandeert dat de som van de netto stromen over de beroepen overeenkomt met de totale netto in- of uitstroom.

In formulevorm:

$\dot{F}_{b}=\dot{F}+\sum_{x} \beta_{b x} D_{x}$

Waarbij:

$\dot{F}_{b}=$ vector van netto in- of uitstroomratio's voor beroep $b$, met waarnemingen per geslacht, leeftijdsklasse en jaar;

$\dot{F}=$ idem, maar dan voor de gehele werkzame bevolking;

$D_{x}=$ matrix met dummy-variabelen; waarden zijn gelijk aan 1 voor cohort $x$ en 0 elders;

$\beta_{b x}=$ random parameters

Vergelijking (4.5) laat zien dat de stromen van de arbeidsmarkt voor een bepaalde beroepsgroep per leeftijdscohort gelijk zijn aan de gemiddelde stroom van de arbeidsmarkt van dat leeftijdscohort, afgezien van beroepsspecifieke afwijkingen die kunnen verschillen 
per leeftijdsklasse. Onder de veronderstelling dat de niet-werkzame beroepsbevolking in de prognoseperiode gelijk blijft, kan met behulp van de door het CPB opgestelde prognoses van de participatiegraad, samen met de bevolkingsprognoses van het $\mathrm{CBS}$, een voorspelling worden gekregen van de toekomstige uitstroom uit de werkzame bevolking $(\dot{F})$. Daarmee wordt met behulp van vergelijking (4.5) tevens een prognose verkregen van de toekomstige netto in- en uitstroomratio's. Deze uitstroomcoëfficiënten worden vervolgens geprojecteerd op de populatie in het basisjaar ${ }^{17}$ om een prognose te kunnen maken van de uitstroom in de komende jaren. Deze prognose wordt gecorrigeerd voor de verwachte verandering in de arbeidsparticipatie per cohort voor de gehele beroepsbevolking. Naast deze participatiecorrectie vindt ook een vergelijkbare correctie plaats voor de conjuncturele situatie in de analyseperiode. Beide correctiefactoren zijn voor alle beroepsklassen en opleidingstypen gelijk.

De correctie voor de conjuncturele situatie is gelijk aan het verschil tussen de verandering in het totale aantal werkende personen en de verandering in de beroepsbevolking in de historische periode. Deze correctie compenseert de uitstroom van werkenden die werkloos zijn geraakt door conjuncturele fluctuaties in het werkgelegenheidsniveau. De correctie voor de verandering in de participatiegraad is het verschil tussen de groei in de beroepsbevolking in de historische periode en de voorspelperiode.

Als de correcties voor de conjunctuur en de participatiegraad gecombineerd worden dan levert dit de voorspelde toekomstige uitstroomratio per cohort op:

$$
\begin{aligned}
\dot{W}_{b x}^{t, m} & =\dot{W}_{b x}^{t, n}-\dot{W} P_{x}^{t, n}+\dot{L} F_{x}^{t, n}+\dot{L} F_{x}^{t, m}-\dot{L} F_{x}^{t, n} \\
& =\dot{W}_{b x}^{t, n}-\dot{W} P_{x}^{t, n}+\dot{L} F_{x}^{t, m}
\end{aligned}
$$

waarbij

$\dot{W}_{b x}^{t, m}=$ de verwachte gemiddelde jaarlijkse netto in- of uitstroomratio van werkenden in beroep $b$, in cohort $x$ op tijdstip $t$ gedurende de voorspelperiode $(t, t+m)$;

$\dot{W}_{b x}^{t, n}=$ de verwachte gemiddelde jaarlijkse netto in- of uitstroomratio van werkenden in beroep $b$, in cohort $x$ op tijdstip $t-n$ gedurende de periode $(t-n, t)$;

$\dot{W} P_{x}^{t, n}=$ de gemiddelde jaarlijkse groeiratio van het totale aantal werkende personen in cohort $x$ op tijdstip $t-n$ gedurende de periode $(t-n, t)$;

$\dot{L} F_{x}^{t, n}=$ de gemiddelde jaarlijkse groeiratio van de beroepsbevolking in cohort $x$ op tijdstip $t-$ $n$ gedurende de periode $(t-n, t)$;

$\dot{L} F_{x}^{t, m}=$ de verwachte gemiddelde jaarlijkse groeiratio van de beroepsbevolking in cohort $\mathrm{x}$ op tijdstip $t$ gedurende de voorspelperiode $(t, t+m)$.

17. Vanwege de kleine aantallen per leeftijdscohort waarop de bewerkingen zijn uitgevoerd, heeft aanvullend onderzoek inmiddels uitgewezen dat het hierbij zinvol te om over twee of drie jaren te middelen. 
Figuur 4.3

Samenvattend overzicht van de methodiek van de vervangingsvraag (excl. specifieke aanpassingen en 'doorleerderscomponent')

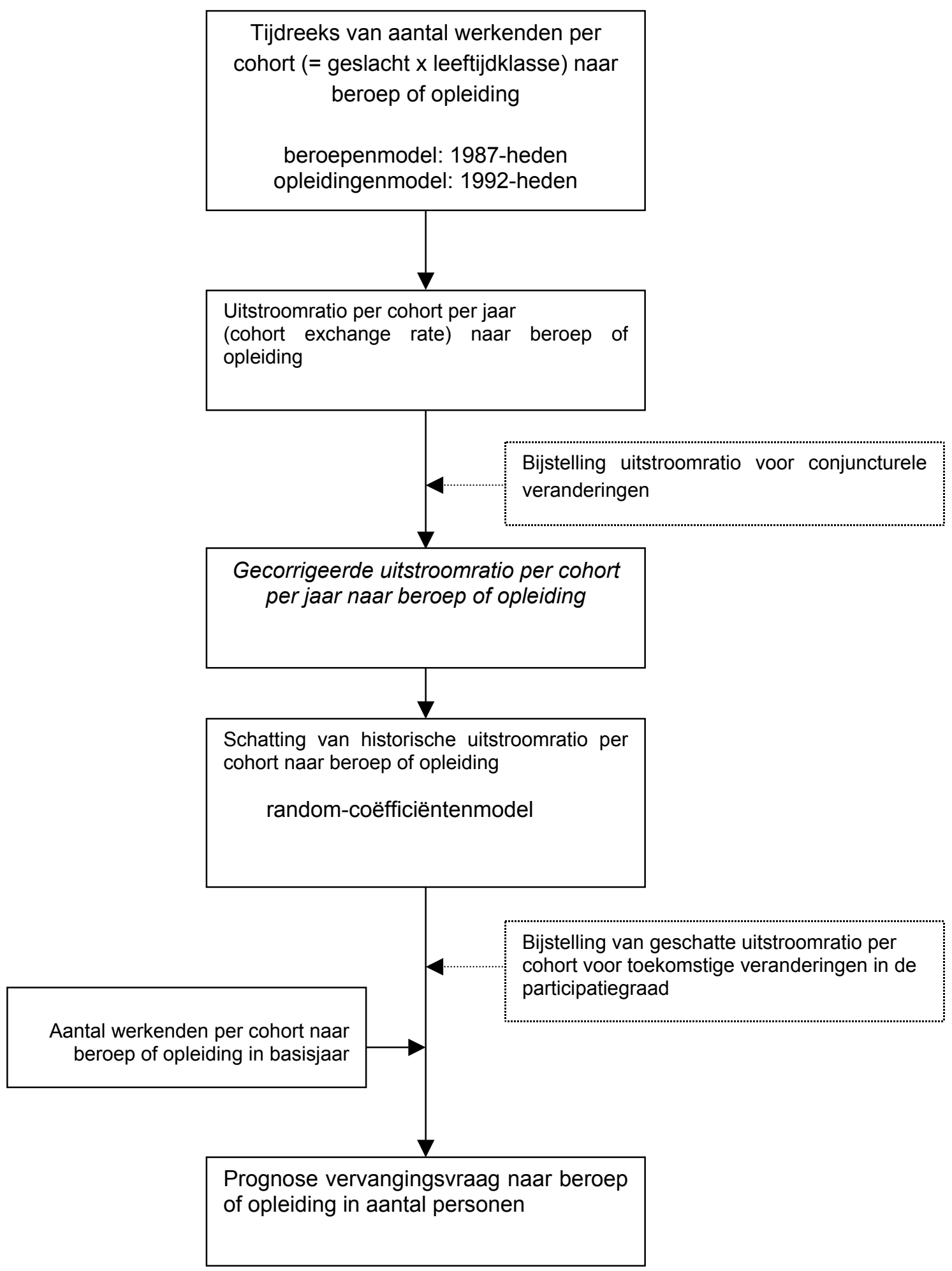

De toekomstige vervangingsvraag wordt vervolgens op dezelfde manier bepaald als de vervangingsvraag in de historische periode. Dit houdt in dat voor beroepsgroepen met een 
verwachte stijging van de werkgelegenheid de vervangingsvraag gelijk is aan de netto uitstroom. De ontwikkeling van de werkgelegenheid per beroepsgroep wordt per geslacht afzonderlijk bekeken. Voor beroepsgroepen waarbij een daling van de werkgelegenheid in een bepaald jaar voor één van beide geslachten wordt verwacht, wordt de vervangingsvraag voor het betreffende jaar en geslacht op nul gesteld. Figuur 4.3 bevat een samenvattend overzicht van de methodiek van het opstellen van de prognoses voor de vervangingsvraag. ${ }^{18}$

\section{Specifieke aanpassingen van uitkomsten}

Vanwege de plausibiliteit van de resultaten heeft ook dit jaar voor een aantal beroepsgroepen een aanpassing van de aldus verkregen vervangingsvraagprognoses moeten plaatsvinden. Deze implausibiliteit wordt met name veroorzaakt door een onbetrouwbare schatting van één of meerdere uitstroomratio's. Deze zijn derhalve aangepast, als regel door deze vast te stellen op het gemiddelde van de ratio van het voorgaande en het volgende leeftijdscohort. Een overzicht van de beroepsgroepen waarvoor de vervangingsvraagprognose op deze wijze is bijgesteld wordt gegeven in tabel 4.2.

\section{Tabel 4.2}

Beroepsgroepen waarvoor de vervangingsvraagprognose is bijgesteld

\begin{tabular}{|c|c|c|}
\hline Beroepsgroep & $\begin{array}{l}\text { Aanpassing in het model } \\
\text { voor mannen }\end{array}$ & $\begin{array}{l}\text { Aanpassing in het model } \\
\text { voor vrouwen }\end{array}$ \\
\hline Bedrijfshoofden metaalbewerking & $\begin{array}{l}\text { Uitstroomcoëfficiënt } \\
\text { bijgesteld voor } 2 \text { cohorten }\end{array}$ & $\begin{array}{l}\text { Uitstroomcoëfficiënt } \\
\text { bijgesteld voor } 3 \text { cohorten }\end{array}$ \\
\hline $\begin{array}{l}\text { Receptionisten en administratieve } \\
\text { employés }\end{array}$ & $\begin{array}{l}\text { Uitstroomcoëfficiënt } \\
\text { bijgesteld voor } 2 \text { cohorten }\end{array}$ & $\begin{array}{l}\text { Uitstroomcoëfficiënt } \\
\text { bijgesteld voor } 2 \text { cohorten }\end{array}$ \\
\hline Hulpkrachten horeca en verzorging & $\begin{array}{l}\text { Uitstroomcoëfficiënt } \\
\text { bijgesteld voor } 2 \text { cohorten }\end{array}$ & $\begin{array}{l}\text { Uitstroomcoëfficiënt } \\
\text { bijgesteld voor } 1 \text { cohort }\end{array}$ \\
\hline
\end{tabular}

Bron: ROA

Tabel 4.3

Opleidingstypen waarvoor de vervangingsvraagprognose is bijgesteld

Opleidingstype

VMBO installatietechniek

MBO vliegtuigtechniek

HBO toerisme en recreatie
Aanpassing in het model voor mannen

Uitstroomcoëfficiënt bijgesteld voor 2 cohorten Uitstroomcoëfficiënt bijgesteld voor 1 cohort Uitstroomcoëfficiënt bijgesteld voor 1 cohort
Aanpassing in het model voor vrouwen

Uitstroomcoëfficiënt bijgesteld voor 1 cohort Uitstroomcoëfficiënt bijgesteld voor 2 cohorten Uitstroomcoëfficiënt bijgesteld voor 4 cohort

Bron: ROA

18. Zie Shah en Burke (2001) voor een vergelijking van de methodiek van de vervangingsvraag naar beroep tussen Australië, de Verenigde Staten en Nederland. 
Ook bij enkele opleidingstypen heeft er een aanpassing plaatsgevonden van de resultaten zoals die met behulp van de hierboven beschreven methodiek zijn verkregen. Deze correcties zijn op vergelijkbare wijze uitgevoerd als bij de beroepen in tabel 4.2. Een overzicht van de opleidingstypen waarvoor de vervangingsvraagprognose moest worden aangepast, is opgenomen in tabel 4.3 .

De toekomstige vervangingsvraag wordt vervolgens op dezelfde manier bepaald als de vervangingsvraag in de historische periode. Dit houdt in dat voor beroepsgroepen met een verwachte stijging van de werkgelegenheid de vervangingsvraag gelijk is aan de netto uitstroom. De ontwikkeling van de werkgelegenheid per beroepsgroep wordt per geslacht afzonderlijk bekeken. Voor beroepsgroepen waarbij een daling van de werkgelegenheid in een bepaald jaar voor één van beide geslachten wordt verwacht, wordt de vervangingsvraag voor het betreffende jaar en geslacht op nul gesteld. Figuur 4.3 bevat een samenvattend overzicht van de methodiek van het opstellen van de prognoses voor de vervangingsvraag. ${ }^{19}$

\section{Vervangingsbehoefte vanwege 'doorleerders'}

Om de vervangingsbehoefte per opleidingstype te bepalen, is dit jaar evenals in $D e$ arbeidsmarkt naar opleiding en beroep tot 2004 (ROA, 1999a) naast de vervangingsbehoefte die uit het beschreven model volgt, een tweede component onderscheiden. Het gaat hier om de vervangingsbehoefte die voortvloeit uit het feit dat sommige werkenden vervolgopleidingen volgen en daarmee een vervangingsbehoefte creëren voor de banen met de opleidingskwalificatie die ze oorspronkelijk hadden. Deze zogenaamde 'doorleerders' zijn dus werkenden die van opleiding veranderen en daarmee impliciet een vervangingsvraag genereren bij hun herkomstopleiding.

Op dit punt moeten de prognoses van de instroom van schoolverlaters en de vervangingsvraag naar opleidingstype vanzelfsprekend goed op elkaar worden afgestemd. Een probleem dat zich hierbij voordoet is dat bij de leeftijdsgroepen 20-24 jaar, 25-29 jaar en 3034 jaar de verwachte vervangingsvraag vanwege de 'uitstroom' van doorlerenden naar een hoger opleidingstype op basis van de bovenstaande methodiek niet goed wordt gemeten, omdat er in deze leeftijdsgroepen nog een aanzienlijke instroom plaatsvindt, waartegen de uitstroomcijfers wegvallen. Daarom baseren we ons voor deze leeftijdsgroep liever op de EBB-cijfers van degenen die door het afronden van een post-initiële opleiding een andere opleidingsachtergrond krijgen. Deze doorleerders veranderen van opleiding en laten een vervangingsvraag achter bij hun herkomstopleiding. De cijfers van de doorleerders naar herkomst vormen een betere afspiegeling voor de (vervangings)vraag in de jonge leeftijdsgroepen, dan de feitelijke uitstroomcijfers.

De bovengenoemde aanpassing is doorgevoerd voor genoemde cohorten en voor alle opleidingen met uitzondering van de opleidingen VMBO verzorging, MBO dokters-, tandarts-

19. Zie Shah en Burke (2001) voor een vergelijking van de methodiek van de vervangingsvraag naar beroep tussen Australië, de Verenigde Staten en Nederland. 
en dierenartsassistent, MBO secretarieel en HBO toerisme in het cohort 30-34 jaar. Voor deze opleidingen die gekenmerkt worden door een groot aantal vrouwelijke afgestudeerden, geven de doorleercijfers naar onze inschatting juist een onderschatting van de feitelijke uitstroom (en daarmee de resulterende vervangingsvraag) te zien. Een tweede aanpassing van de vervangingsvraagprognose-methodiek is dat voor de opleidingen met een netto instroom in het cohort 30-34 jaar, de vervangingsvraag wordt verhoogd met de doorlerenden in deze leeftijdsgroep.

De vervangingsvraagprognoses per opleidingstype zijn deze keer meer beïnvloed door het meenemen van de doorleerderscomponent dan in 1999 het geval was. Dit omdat de verwachte groep doorleerders voor de periode 2001-2006 veel groter is dan in de periode 1999-2004. Omdat het uiteindelijk gaat om de vervangingsbehoefte die voortvloeit uit het feit dat sommige werknemers vervolgopleidingen volgen en daarmee een vervangingsbehoefte creëren voor de banen met de opleidingskwalificatie die ze oorspronkelijk hadden, houdt dit voor sommige opleidingstypen in dat de doorleerders de totale vervangingsvraag aanzienlijk opstuwen. Het hier vooral gaat om de lagere en middelbare opleidingstypen.

\subsection{Methodiek instroom van schoolverlaters op de arbeidsmarkt}

De prognoses van de instroom op de arbeidsmarkt zijn gebaseerd op een verdeelmodel, dat een stapsgewijze modulaire opbouw heeft. Figuur 4.4 geeft een schematisch overzicht van deze opbouw. In het prognosemodel worden globaal gesproken twee stappen onderscheiden. In de eerste stap wordt de prognose opgesteld van de verwachte toekomstige uitstroom uit het regulier voltijdonderwijs. Niet voor alle schoolverlaters eindigt na het verlaten van het regulier voltijdonderwijs echter de schoolloopbaan. Na het verlaten van het voltijdonderwijs kan men immers nog doorstromen naar het deeltijdonderwijs, het nietreguliere voltijdonderwijs en de beroepsgerichte volwasseneneducatie. Als men daar een diploma behaald heeft en de gevolgde opleiding heeft een hoger niveau of een andere opleidingsrichting dan de genoten vooropleiding, dan moet de instroomprognose worden bijgesteld. Deze bijstelling vindt plaats in stap twee.

\section{Stap 1}

Figuur 4.5 geeft een overzicht van de opzet van stap 1 van het prognosemodel. De gebruikte databronnen zijn weergegeven in de grijsgetinte vakken. Uitgangspunt bij de bepaling van de verwachte toekomstige instroom van schoolverlaters op de arbeidsmarkt is de beleidsarme variant van de Referentieraming van het Ministerie van Onderwijs, Cultuur en Wetenschappen (2001). Uit de Referentieraming worden de prognoses van het aantal schoolverlaters naar schoolsoort en -richting voor het voltijd- en deeltijdonderwijs gebruikt. Hierbij is in de Referentieraming een onderscheid gemaakt tussen de schoolverlaters met diploma en de schoolverlaters zonder diploma. Degenen die het regulier voltijdonderwijs zonder diploma verlaten, kunnen eerder een opleiding met diploma hebben afgesloten. De ongediplomeerde schoolverlaters worden daarom toegewezen aan hun eerdere hoogst voltooide vooropleiding in het voltijdonderwijs. Deze hoogst voltooide voltijdopleiding wordt 
Figuur 4.4

Globaal schema ter bepaling van de verwachte toekomstige instroom van schoolverlaters op de arbeidsmarkt naar ROA-opleidingstype

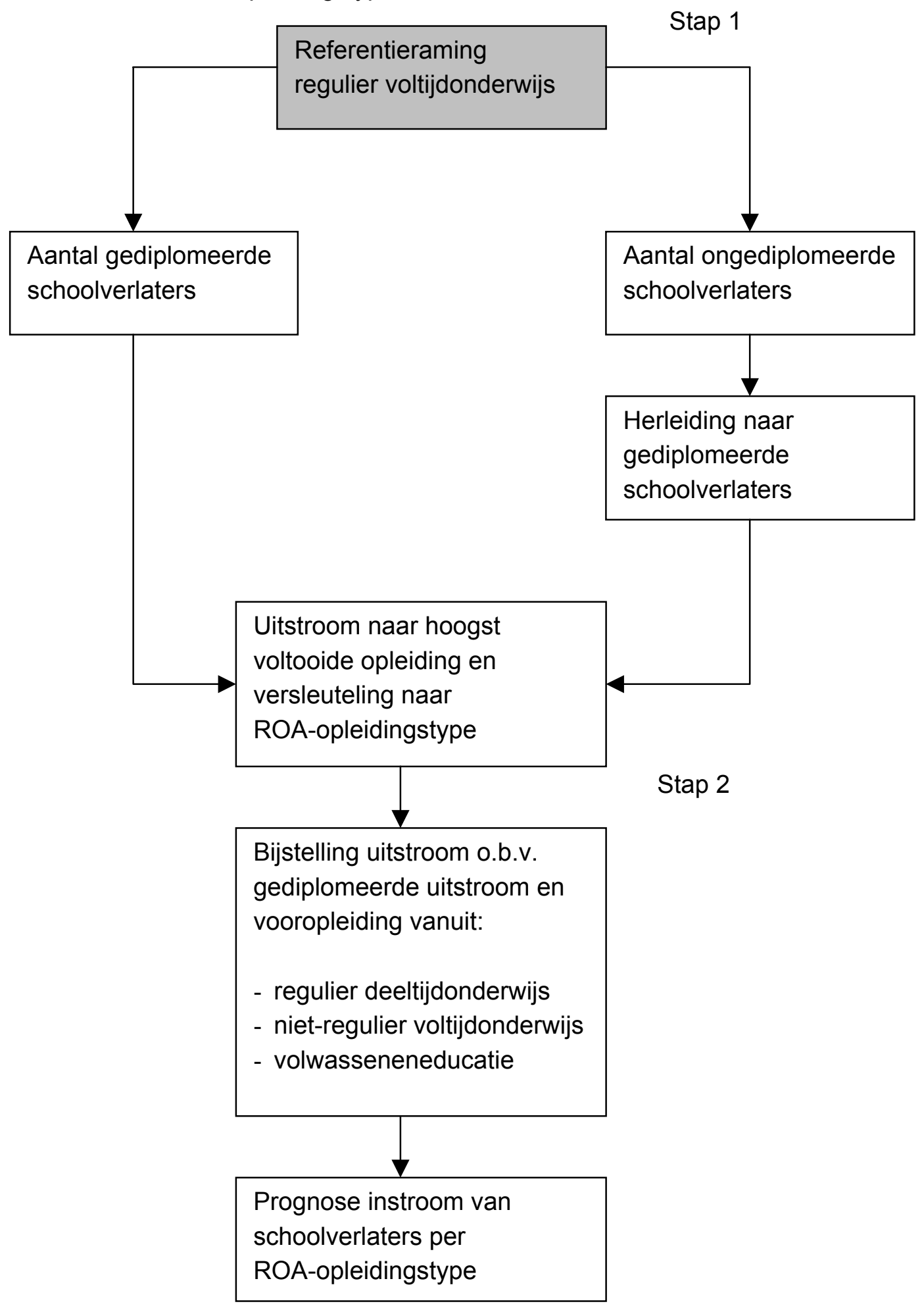


Figuur 4.5

Globaal overzicht van de eerste stap van de instroomprognoses van schoolverlaters op de arbeidsmarkt

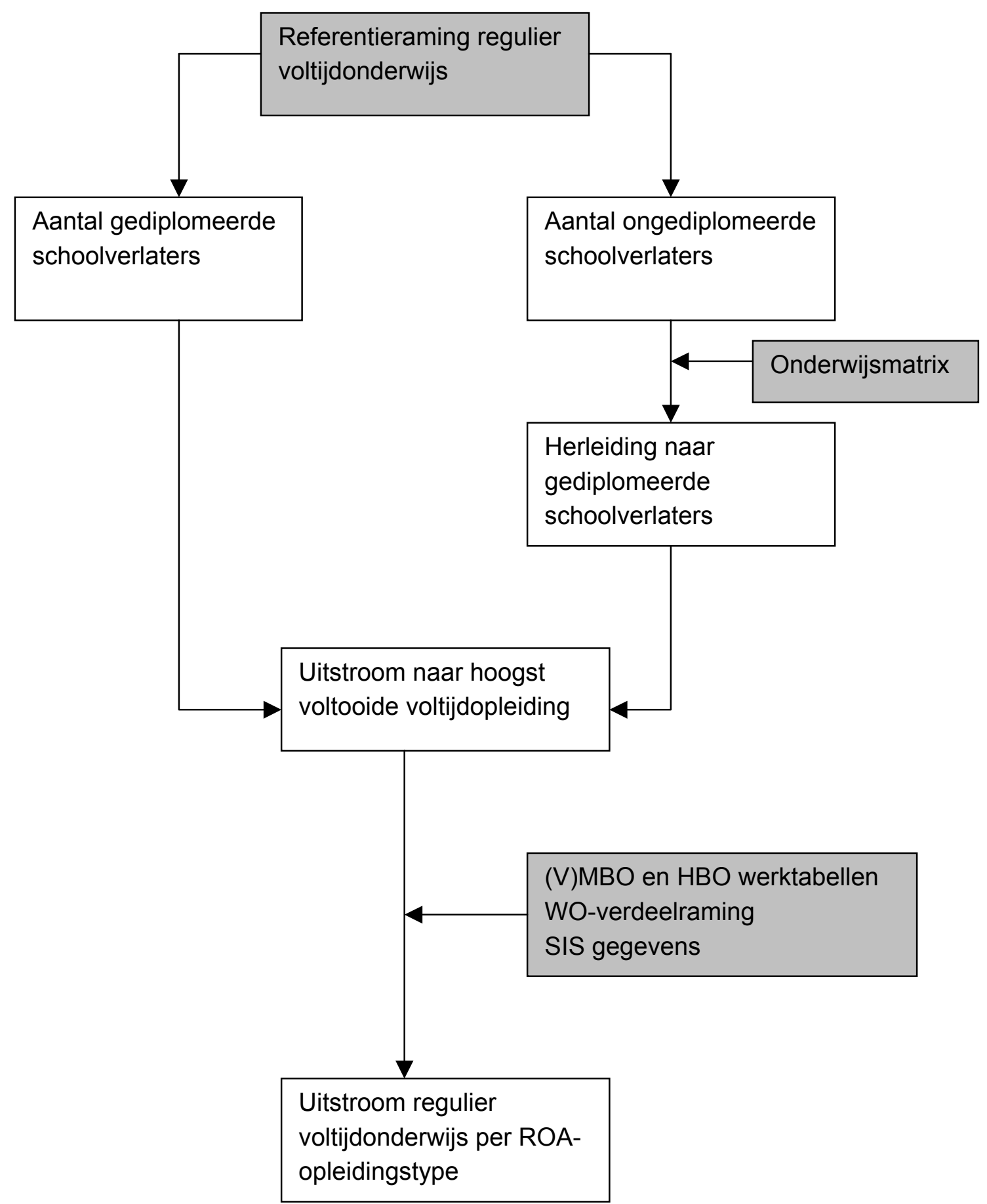


vastgesteld aan de hand van de Onderwijsmatrix 1998 van het CBS. ${ }^{20}$ Dit resulteert in het verwachte aantal gediplomeerde schoolverlaters per schoolsoort en -richting.

De indeling van opleidingen op basis van de onderwijsmatrix heeft een hoger aggregatieniveau dan de indeling die het ROA hanteert. Daarom vindt er een uitsplitsing plaats om de toekomstige uitstroom uit het regulier voltijdonderwijs naar de arbeidsmarkt per ROAopleidingstype te bepalen. Deze verdeling wordt gemaakt met behulp van gegevens over het aantal gediplomeerden van elk opleidingstype binnen een schoolsoort, de CBSwerktabellen. ${ }^{21}$ In deze tabellen worden de gediplomeerden op twee aggregatieniveaus weergegeven. Op basis van het hogere aggregatieniveau worden de CBS-werktabellen aan de Referentieraming gekoppeld en op basis van het lagere niveau wordt de procentuele verdeling berekend waarmee de gegevens uit de Referentieraming worden vermenigvuldigd. Voordat dit gebeurt, dient echter een correctie te worden uitgevoerd op de werktabellen. Omdat namelijk niet alle gediplomeerden schoolverlaters zijn, kan de verdeling van het aantal gediplomeerden afwijken van de verdeling van het aantal schoolverlaters. Op basis van de gegevens uit de RUBS-enquête, de HBO-Monitor en de WO-Monitor (kortweg SISgegevens) wordt het aandeel schoolverlaters binnen de groep gediplomeerden bepaald. Met deze gegevens wordt vervolgens de verdeling van de gediplomeerden over de opleidingsrichtingen binnen de schoolsoorten bijgesteld in de CBS-werktabellen. Ten slotte wordt met behulp van de SOl-codes (zie bijv. de ROA-classificatiegids 2002), behorende bij de opleidingen in de CBS-werktabellen, de indeling op het laagste aggregatieniveau naar ROAindeling berekend. Tevens is voor het wetenschappelijk onderwijs specifiekere informatie gebruikt. De WO-verdeelraming 2000 geeft prognoses voor 73 WO-opleidingen.

Deze kunnen op basis van CROHO-codes via het SIS aan de Standaard-Onderwijs-Indeling van het CBS (en dus ook de ROA-indeling) gerelateerd worden. Na stap 1 zijn de instroomprognoses voor schoolverlaters en afgestudeerden van het voltijdonderwijs gereed.

\section{Stap 2}

In stap 2 wordt, zoals reeds is aangegeven, de instroomprognose aangepast door rekening te houden met de doorstroom naar het deeltijdonderwijs, inclusief de beroepsbegeleidende leerweg (BBL, het voormalige leerlingwezen), het niet-reguliere voltijdonderwijs of de beroepsgerichte volwasseneneducatie. Als iemand een dergelijke opleiding met een diploma afsluit en de gevolgde opleiding heeft betrekking op een ander opleidingstype dan de

20. In de prognoses wordt het MBO-gedeelte uit de Onderwijsmatrix 1996 gebruikt omdat er in de Onderwijsmatrix 1998 door het CBS geen opsplitsing naar schoolrichting kon worden gemaakt voor het MBO vanwege de onbetrouwbaarheid van de data.

21. De gegevens hebben betrekking op de periode van de laatste vijf jaren. Op basis hiervan wordt een trend in het aantal gediplomeerden per opleiding berekend. De gegevens van de lagere en middelbare beroepsopleidingen zijn op basis van CFI-tellingen van het Ministerie van OCenW vastgesteld en worden aan de hand van CREBO-codes gekoppeld aan de SOI '78. Voor het Hoger Onderwijs zijn de cijfers vastgesteld op basis van tellingen van de Informatie Beheer Groep. De opleiding kunnen met de CROHO-codes worden gekoppeld aan de SOI ' 78 . 
gevolgde vooropleiding dan neemt de instroom op de arbeidsmarkt van het betreffende opleidingstype toe. ${ }^{22}$

Voor de arbeidsmarktinstroom van schoolverlaters van de beroepsbegeleidende leerweg in het regulier bekostigde onderwijs is gebruik gemaakt van de ramingen voor de beroepsbegeleidende leerweg (BBL) in de Referentieraming 2001. Deze aantallen zijn verbijzonderd naar opleidingstype aan de hand van gegevens over het BBL (c.q. leerlingwezen) uit de Onderwijsrekeningen 1997. Bij de berekening van het niet-reguliere aanbod (excl. BBL) is gebruik gemaakt van de Onderwijsrekeningen van het CBS. Deze databron geeft informatie over de mate waarin werkenden met een bepaalde initiële opleidingsachtergrond na hun intrede op de arbeidsmarkt door het volgen van een aanvullende opleiding een andere opleidingsachtergrond krijgen. De meest recente gegevens uit deze databron zijn beschikbaar voor het jaar 1997 (De Grip en Jacobs, 1999). Nadat stap 2 is uitgevoerd resulteert de toekomstige instroom van schoolverlaters op de arbeidsmarkt per opleidingstype voor de prognoseperiode 2001-2006.

\subsection{Typering arbeidsmarktperspectieven}

Voor de opleidingen kunnen de verwachte vraag naar nieuwkomers en het verwachte aanbod aan elkaar worden gerelateerd. Als aanbod is de som genomen van de verwachte instroom in de periode 2001-2006 en het aantal werklozen aan het begin van de prognoseperiode dat korter dan 1 jaar werkloos is. Dit laatste is op te vatten als het boven de markt zwevende aanbod van werklozen aan het begin van de prognoseperiode.

De verwachte vraag bestaat uit de som van de uitbreidings- en de vervangingsvraag. Voor zover nieuwkomers op de arbeidsmarkt hinder ondervinden van een krimpende werkgelegenheid, wordt dit met de vervangingsvraag verrekend (zie paragraaf 4.3). De vervangingsvraag wordt immers alleen beïnvloed door de uitstroom van werkenden voor zover dit tot nieuwe vraag leidt. Daarnaast wordt aan de vraagkant rekening gehouden met de substitutievraag. Vervolgens wordt de Indicator Toekomstige Arbeidsmarktsituatie (ITA) bepaald volgens de formule:

$$
I T A=\frac{(100+\text { instroom } \%+\text { kortdurig werklozen } \%)}{(100+\max \{0, \text { uitbreidingsvraag } \%\}+\text { vervangingsvraag } \%+\text { substitutievraag } \%)}
$$

Naarmate de waarde van de ITA hoger ligt, is er sprake van een slechter arbeidsmarktperspectief. Een waarde rond de 1 duidt op een evenwichtssituatie. Om te bewerkstelligen dat de grens tussen een goed en een redelijk perspectief precies bij 1 ligt en om discrepanties tussen de ITA en de typering te voorkomen, wordt de ITA naar boven afgerond.

22. Bovendien wordt de vervangingsvraag van het opleidingstype waarbinnen de vooropleiding valt navenant verhoogd (zie paragraaf 4.3). 


\subsection{Typering knelpunten in de personeelsvoorziening}

\section{Knelpunten naar opleidingstype}

Naast de verwachte arbeidsmarktsituatie voor nieuwkomers is ook ingegaan op de verwachte knelpunten in de personeelsvoorziening. De indicator hiervoor is in principe het spiegelbeeld van de ITA. Als de vraag naar werkenden met een bepaalde opleidingsachtergrond groter is dan het aanbod kunnen knelpunten in de personeelsvoorziening verwacht worden. Vergelijkbaar met de Indicator Toekomstige Arbeidsmarktsituatie (ITA) geeft de Indicator van de Toekomstige Knelpunten in de Personeelsvoorziening (ITKP) deze vraag-aanbodspanning aan. Bij een krimpende werkgelegenheid voor een bepaald opleidingstype wordt de totale vraag ('recruteringsbehoefte') echter op een enigszins andere wijze berekend dan het aantal baanopeningen voor nieuwkomers op de arbeidsmarkt. Verschil met de ITA is dat bij de ITKP de uitstroom van werkenden als gevolg van een krimpende werkgelegenheid is meegerekend in de vraag, omdat verwacht mag worden dat bij knelpunten in de personeelsvoorziening deze (gedwongen) uitstroom kan worden afgeremd of elders werk zou kunnen vinden. Zeker wanneer bedrijven geconfronteerd worden met een krappe arbeidsmarkt voor een bepaald opleidingstype, zullen zij van deze mogelijkheid gebruik maken. Voor het overige is de Indicator Toekomstige Knelpunten in de Personeelsvoorziening (ITKP) gelijk aan de ITA. Naarmate de waarde van de indicator lager wordt, zijn de verwachte knelpunten in de personeelsvoorziening groter.

$$
I T K P=\frac{(100+\text { instroom } \%+\text { kortdurig werklozen } \%)}{(100+\text { uitbreidingsvraag } \%+\text { vervangingsvraag } \%+\text { substitutievraag } \%)}
$$

\section{Knelpunten naar beroepsgroep}

Voor het indiceren van de knelpunten in de personeelsvoorziening naar beroepsgroep kan niet een soortgelijke aanpak worden gevolgd, omdat het aanbod per beroepsgroep niet goed is vast te stellen. Daarom is een indicator ontwikkeld waarvoor geen voorspellingen van het arbeidsaanbod naar beroep nodig zijn.

De knelpunten in de personeelsvoorziening naar beroepsgroep nemen de prognoses van vraag en aanbod naar opleidingstype als uitgangspunt. Daarbij is als volgt te werk gegaan.

Het aanbod van een opleidingstype $i$ op tijdstip $t\left(\right.$ aanbod $\left._{i, t}\right)$ is gelijk aan het aanbod op tijdstip $t$-1 (het 'basisjaar' van de prognoseperiode) plus de arbeidsmarktinstroom van schoolverlaters in de periode tussen $t-1$ en $t$ minus de vervangingsvraag over dezelfde periode:

$\operatorname{aanbod}_{i, t}=x_{i, t-1}+w h_{i, t-1}+$ nieuw $_{i}-v v_{i}$

waarbij:

$x_{i, t-1} \quad$ het totaal aantal werkenden met opleiding $i$ in $t-1$ 


$\begin{array}{ll}w l h_{i, t-1} & \text { het aantal kortdurige werklozen met opleidingstype } i \text { in } t-1 \\ n i e u w_{i} & \text { de arbeidsmarktinstroom van schoolverlaters met opleidingstype } i \text { voor de } \\ & \text { periode tussen } t-1 \text { en } t\end{array}$

De kans om een werknemer aan te trekken met opleidinstype $i$ wordt gegeven door:

$$
\begin{array}{ll}
p_{i}=\frac{\text { aanbod }_{t, t}}{x_{i, t}} & \text { als aanbod }_{\mathrm{i}, \mathrm{t}} \leq \mathrm{x}_{\mathrm{i}, \mathrm{t}} \\
p_{i}=1 & \text { als aanbod } \\
\mathrm{i}, \mathrm{t} & >\mathrm{x}_{\mathrm{i}, \mathrm{t}}
\end{array}
$$

$x_{i, t}$ is de verwachte vraag naar opleiding $i$ op tijdstip $t$. We veronderstellen dus dat de kans om iemand met opleidingstype $i$ aan te trekken gelijk is voor alle beroepsgroepen. Dat betekent dat tekorten proportioneel over beroepen verdeeld zullen zijn.

De alternatieve indicator voor de toekomstige knelpunten in de personeelsvoorziening naar beroepsgroep $\left(\right.$ ITKB $_{\mathrm{j}}$ ) als gevolg van aanbodtekorten bij opleidingen waaruit de werkenden in beroep $j$ worden gerecruteerd, wordt dan gegeven door:

$$
I T K B_{j}=\frac{\sum_{i} p_{i} x_{i j, t}}{\sum_{i} x_{i j, t}} ; \quad 0 \leq I T K B_{j} \leq 1
$$

De $I T K B_{j}$ is een relatieve maatstaf voor knelpunten. De noemer geeft de totale vraag vanuit beroepsgroep $j$ en de teller de verwachte vervulling van deze vraag. De ITKB geeft dus de mate waarin de vraag vanuit beroepsgroep $j$ in de gewenste samenstelling vervuld zal kunnen worden. Naarmate de waarde van $I T K B_{j}$ lager is, zijn er meer knelpunten te verwachten. Als $I T K B j=1$ dan worden er geen knelpunten verwacht bij het vervullen van de vraag vanuit beroepsgroep $j$. Een $I T K B_{j}$ van 0 betekent derhalve dat de vraag vanuit beroep $j$ in het geheel niet vervuld kan worden.

Deze indicator heeft echter een nadeel. De indicator geeft aan in welke mate het mogelijk is om de gewenste personeelsamenstelling te bereiken maar houdt geen rekening met de mogelijkheid om tekorten bij een opleiding aan te vullen door mensen met een andere (aanverwante) opleiding te rekruteren. Met eventuele substitutieprocessen wordt dus geen rekening gehouden. Dit impliceert dat een eventuele vermindering van de knelpunten als gevolg van passief substitutie-aanbod vanuit andere opleidingen in deze alternatieve indicator niet tot uiting komen. 


\section{De structurele arbeidsmarktsituatie}

\subsection{Inleiding}

Naast de informatie over de actuele arbeidsmarktsituatie en de prognoses voor de ontwikkelingen op de arbeidsmarkt voor de middellange termijn, verschaft het informatiesysteem onderwijs-arbeidsmarkt ook inzicht in de structurele arbeidsmarktpositie van beroepsgroepen en opleidingstypen. Deze indicatoren beogen de kracht of kwetsbaarheid van een bepaalde beroepsgroep of opleidingsachtergrond op de arbeidsmarkt aan te duiden, ongeacht de specifieke actuele situatie of de voorspelde ontwikkelingen in de vraag-aanbodverhoudingen.

Het gaat hierbij om de indicator voor de conjunctuurgevoeligheid van de werkgelegenheid en de indicatoren voor de uitwijkmogelijkheden op de arbeidsmarkt. Daarnaast is ook gebruik gemaakt van een indicator voor de substitutiemogelijkheden die werkgevers hebben tussen arbeidskrachten met uiteenlopende opleidingsachtergronden en de concurrentie-index die aangeeft welke opleidingen een sterke verwantschap vertonen in hun beroependomein.

In dit hoofdstuk worden deze indicatoren besproken. Paragraaf 5.2 bespreekt de indicator voor de conjunctuurgevoeligheid. Daarna wordt in paragraaf 5.3 ingegaan op de indicatoren van en de substitutiemogelijkheden op de arbeidsmarkt en de uitwijkmogelijkheden. Ten slotte wordt in paragraaf 5.4 ingegaan op de concurrentie-index.

\subsection{Conjunctuurgevoeligheid}

De indicator voor de conjunctuurgevoeligheid geeft aan in welke mate de werkgelegenheid voor een bepaalde beroepsgroep of opleidingstype fluctueert als gevolg van schommelingen in de werkgelegenheid van bedrijfssectoren. De conjunctuurgevoeligheid van bedrijfssectoren wordt vastgesteld op grond van: ${ }^{23}$

$$
C l_{s}=100 x \sum_{t} \frac{\left|W_{s}^{t}-\bar{W}_{s}^{t}\right|}{w^{t}}
$$

waarbij:

$\mathrm{Cl}_{s} \quad$ conjunctuurgevoeligheid van bedrijfssector $s$

$w_{s}^{t} \quad$ de werkgelegenheid in bedrijfssector $s$ in jaar $i$

$\bar{w}_{s}^{t} \quad$ de trend van de werkgelegenheid in bedrijfssector $s$ in jaar $t$.

De trend wordt berekend als:

$$
\bar{W}_{s}^{t}=\frac{W_{s}^{t-1}+W_{s}^{t+1}}{2}
$$

23. De conjunctuurindicator wordt hierbij nog wel genormeerd naar de waarde 1. 
De indicator wordt vastgesteld op basis van gegevens van het totale arbeidsvolume uit de Nationale Rekeningen voor de periode 1977 tot 2001. ${ }^{24}$ In de praktijk blijken echter de productieberoepen sterker beïnvloed te worden door deze schommelingen dan andere functies. Om hiervoor te corrigeren wordt het verband vastgesteld tussen de werkgelegenheidsfluctuaties in een beroepssegment $\Delta W_{p s}^{t}$ en de schommelingen in een bedrijfssector:

$$
\Delta W_{p s}^{t}=C_{p s}+\alpha_{p s} \Delta W_{s}^{t}
$$

Dit verband is geschat op basis van de EBB van 1996 tot 2001. $\alpha_{p s}$ geeft aan in welke mate de werkgelegenheid in een bepaald beroepssegment meefluctueert met de werkgelegenheid van de bedrijfssector. De conjunctuurgevoeligheid van een beroepsgroep $b$ is vastgesteld als: ${ }^{25}$

$$
C l_{b}=\sum_{s} \frac{W_{b s}^{2001}}{W_{s}^{2001}} \alpha_{p s} C l_{s}
$$

Hierbij is $p$ het beroepssegment dat beroepsgroep $b$ omvat. Omdat bij een aantal beroepen waarbij het aandeel in de werkgelegenheid in een bedrijfssector vrij klein is, de schattingen van $\alpha_{p s}$ vrij extreme waarden aannamen, is de randvoorwaarde gesteld dat $\alpha_{p s}$ tussen 0,3 en 3,0 moet liggen.

Omdat de werkgelegenheid van mensen met een bepaalde opleidingsachtergrond deels ook aanbodbepaald is, is een soortgelijke aanpak voor de berekening van de conjunctuurgevoeligheid van opleidingstypen niet zinvol. Om die reden is bij het bepalen van de conjunctuurgevoeligheid van een bepaald opleidingstype het gewogen gemiddelde genomen van de beroepsgroepen waarin degenen uit deze opleidingsachtergrond werkzaam zijn.

$$
C l_{O}=\sum_{b} \frac{W_{o b}^{2001}}{W_{b}^{2001}} C l_{b}
$$

\subsection{Uitwijk- en substitutiemogelijkheden}

Omdat er in het algemeen geen één-op-één-relatie bestaat tussen opleiding en beroep of tussen opleiding en bedrijfssector is het zinvol om aan te geven hoe breed het domein is waarin mensen met een bepaalde opleidingsachtergrond werk vinden. De maatstaf die hiervoor wordt gebruikt is de Gini-Hirschman-index. De spreiding van een opleidingstype over beroepsgroepen wordt aangegeven door:

24. Zie CBS $(1995,1996)$ voor de oudere tijdreeksen.

25. Ook hier wordt de conjunctuurindicator wordt hierbij nog wel genormeerd naar de waarde 1. 


$$
G H_{o}^{b e r}=\frac{1}{\sum_{b}\left(\frac{W_{o, b}}{W_{o}}\right)^{2}}
$$

Deze maatstaf kan geïnterpreteerd worden als het gestandaardiseerde aantal beroepen waarin men terecht komt. Bij een volledige concentratie van de werkgelegenheid in één beroepsgroep is de indicator gelijk aan 1. Bij een gelijke spreiding over $n$ beroepsgroepen is de indicator gelijk aan $n$. Bij een ongelijke spreiding tellen beroepsgroepen met een relatief laag werkgelegenheidsaandeel minder zwaar mee dan beroepsgroepen met een groot werkgelegenheidsaandeel. Op vergelijkbare wijze kunnen de uitwijkmogelijkheden van een opleidingstype of een beroepsgroep naar bedrijfssectoren worden vastgesteld.

Daarnaast wordt een indicatie gegeven van de substitutiemogelijkheden die een werkgever heeft in de selectie van mensen met een uiteenlopende opleidingsachtergrond. Daarbij is de spreiding van de werkgelegenheid in een beroepsgroep over de opleidingstypen als volgt vastgesteld:

$$
G H_{b}^{\text {subs }}=\frac{1}{\sum_{o}\left(\frac{W_{o, b}}{W_{b}}\right)^{2}}
$$

\subsection{Concurrentie-index}

Naast het feit dat een opleidingstype tot werk in meerdere beroepen kan leiden, kan er tussen de werkgelegenheid van opleidingstypen ook een overlap bestaan. De concurrentieindex die hiervoor wordt gebruikt (zie Borghans, 1992) is afgeleid van de Gini-Hirschmanindex en luidt als volgt:

$$
S_{o, 00}=\frac{\sum_{b}\left(\frac{W_{o, b}}{W_{o}}\right)\left(\frac{W_{o o, b}}{W_{o o}}\right)}{\sqrt{\sum_{b}\left(\frac{W_{o, b}}{W_{o}}\right)^{2} \sum_{b}\left(\frac{W_{o o, b}}{W_{o o}}\right)^{2}}}
$$

Deze index geeft aan hoe groot de kans is dat personen met een verschillende opleidingsachtergrond (respectievelijk $o$ en oo) in dezelfde beroepsgroep werkzaam zijn. Omdat bij opleidingstypen met een grote beroepenspreiding deze kans a priori reeds klein is, is deze voor beroepenspreiding gecorrigeerd. 


\section{Literatuur}

Borghans L. (1992), A Histo-Topographic Map of the Dutch University Studies, ROA-W-1992/5E, Maastricht.

Borghans, L. (1996), Effects of supply and demand on the employment structure, Maastricht.

Borghans, L., A. de Grip, H. Heijke (2000), Alice in prognoseland. Over de zin van arbeidsmarktprognoses, ROA-W-2000/6, Maastricht.

Borghans, L., A. de Grip, E. Willems (1995), Herijking ROA-Informatiesysteem OnderwijsArbeidsmarkt, ROA-R-1995/1, Maastricht.

Borghans, L., H. Heijke (1994), Een random-coëfficiënten-model voor het voorspellen van de beroepenstructuur van bedrijfstakken, ROA-W-1994/1, Maastricht.

Borghans, L., H. Heijke (1996), Forecasting the Educational Structure of Occupations: a Manpower Requirement Approach with Substitution, Labour, Vol. 10, pp. 151-192.

Borghans, L., E. Willems (1998), Interpreting Gaps in Manpower Forecasting Models, Labour, Vol. 12, pp. 663-641.

Centraal Bureau voor de Statistiek (1993), Standaard Beroepenclassificatie 1992, Sdu, Den Haag.

Centraal Bureau voor de Statistiek (1995), Nationale Rekeningen: gereviseerde reeksen 1977-1986, Voorburg/Heerlen.

Centraal Bureau voor de Statistiek (1996), Nationale Rekeningen: gereviseerde reeksen 1969-1976, Voorburg/Heerlen.

Centraal Bureau voor de Statistiek (1999), Enquête Beroepsbevolking 1998, Voorburg/Heerlen.

Centraal Planbureau (1990), ATHENA Een bedrijfstakkenmodel voor de Nederlandse economie, Werkdocument No. 30, Den Haag.

Centraal Planbureau (1997), Omgevingsscenario's Lange Termijn Verkenning 1995-2020, Werkdocument No. 89, Den Haag.

Centraal Planbureau (2001), Centraal Economisch Plan 2001, Den Haag.

Cörvers, F., A. de Grip and H. Heijke (2002), Beyond manpower planning: a labour market model for the Netherlands and its forecasts to 2006, in: M. Neugart and K. Schömann (eds), Forecasting Labour Markets in OECD countries, Edward Elgar.

Eijs, P. van, A. de Grip (1998) De ontwikkeling van het project onderwijs-arbeidsmarkt 1986-1998, ROA-W-1998/7, Maastricht.

Eijs, P. van, A. de Grip, B. Diephuis, A. Jacobs, Ph. Marey, M. de Steur (2000), Methodiek arbeidsmarktprognoses en -indicatoren 1999-2004, ROA-W-1999/4, Maastricht.

Grip, A. de, L. Borghans, W. Smits (1998), Future Developments in the Job Level and Domain of High-skilled Workers, in: H. Heijke, L. Borghans (eds), Towards a Transparent Labour Market for Educational Decisions, Ashgate, Aldershot/Brookfield USA/Singapore/Sydney, 1998, pp. 21-56.

Grip, A. de, H. Heijke (1998), Beyond Manpower Planning: ROA's Labour Market Model and its Forecasts to 2002, ROA-W-1998/6E, Maastricht.

Grip, A. de, A. Jacobs (1999), De doorstroom van het initieel naar het niet-initieel onderwijs, ROA-W1999/3, Maastricht. 
Grip, A. de, R.K.W. van der Velden, M.H. Wieling (1991), Indicatoren aansluiting onderwijsarbeidsmarkt MDGO. Enkele arbeidsmarktindicatoren op basis van de RUBS-data, ROA-R1991/2, Maastricht.

Heijke, H., A. Matheeuwsen, E. Willems (2002), Clustering Educational Categories in a Heterogeneous Labour Market, Education Economics, 10 (4).

Marey, Ph. (2002), The speed of skill-upgrading in the Netherlands, ROA working paper, te verschijnen.

Ministerie van Onderwijs, Cultuur en Wetenschappen (2001), Referentieraming 2001, Zoetermeer.

Researchcentrum voor Onderwijs en Arbeidsmarkt (1999a), De arbeidsmarkt naar opleiding en beroep 2004, ROA-R-1999/8, Maastricht.

Researchcentrum voor Onderwijs en Arbeidsmarkt (1999b), De arbeidsmarkt naar opleiding en beroep tot 2004. Statistische bijlage, ROA-R-1999/8B, Maastricht.

Researchcentrum voor Onderwijs en Arbeidsmarkt (2001), De arbeidsmarkt naar opleiding en beroep 2006, ROA-R-2001/8, Maastricht.

Researchcentrum voor Onderwijs en Arbeidsmarkt (2002a), ROA-classificatiegids 2002, ROA-R2002/3, Maastricht.

Researchcentrum voor Onderwijs en Arbeidsmarkt (2002b), Schoolverlaters tussen onderwijs en arbeidsmarkt 2001, ROA-R-2002/8, Maastricht.

Shah, C., G. Burke (2001), Occupational Replacement Demand in Australia, International Journal of Manpower, Vol. 22, pp. 648-663.

Shyrock, H.S., J.S. Siegel (1980), The Methods and Materials of Demography, U.S. Bureau of the Census, U.S. Printing Office, Fourth Printing (rev.), Washington D.C.

Smoorenburg, M.S.M. van, R.K.W van der Velden (1995), Schoolverlaters op de arbeidsmarkt, De uitstroom en bestemming van het schooljaar 1992-1993, Leeuwarden.

Wieling M.H., A. de Grip, E.J.T.A. Willems, Een systematische kwalitatieve typering van arbeidsmarktinformatie, ROA-W-1990/8, Maastricht.

Willems, E. (1999), Modelling Replacement Demand: a Random Coefficient Approach, ROA-RM1999/2E.

Willems, E.J.T.A., A. de Grip (1993), Forecasting Replacement Demand by Occupation and Education, International Journal of Forecasting, vol. 9, nr. 2, pp. 173-185. 



\section{Appendix A}

De grenzen en typering hebben betrekking op de gegevens in het POA-informatiesysteem die, met uitzondering van de middellangetermijnprognoses, in het najaar van 2002 geactualiseerd zijn.

Tabel A.1

Grenzen kwalitatieve typering bedrijfssectoren

\begin{tabular}{lcccc}
\hline Typering & $\begin{array}{c}\text { erg laag } \\
\text { t.o.v. laag }\end{array}$ & $\begin{array}{c}\text { laag t.o.v. } \\
\text { gemiddeld }\end{array}$ & $\begin{array}{c}\text { gemiddeld } \\
\text { t.o.v. hoog }\end{array}$ & $\begin{array}{c}\text { hoog t.o.v. } \\
\text { erg hoog }\end{array}$ \\
\hline Percentage vrouwen & 9,76 & 19,88 & 37,17 & 44,72 \\
Percentage jongeren (15-29 jaar) & 15,25 & 18,88 & 24,75 & 28,97 \\
Percentage ouderen (50-64 jaar) & 14,47 & 18,08 & 21,77 & 23,81 \\
Percentage allochtonen naar etniciteit & 2,41 & 3,79 & 6,67 & 8,99 \\
Percentage allochtonen naar herkomst & 4,25 & 5,89 & 9,42 & 12,55 \\
Percentage deeltijdarbeid & 7,70 & 11,28 & 24,63 & 35,77 \\
Percentage zelfstandigen & 0,32 & 2,36 & 13,28 & 23,27 \\
Percentage flexibel werk & 4,14 & 5,56 & 9,52 & 14,49 \\
Percentage werknemers met vast werk & 75,39 & 89,73 & 94,29 & 95,23 \\
Conjunctuurgevoeligheid & 0,47 & 0,59 & 1,09 & 1,37 \\
Verwachte uitbreidingsvraag (\%) & -10 & -1 & 5 & 9 \\
\hline
\end{tabular}


Tabel A. 2

Grenzen kwalitatieve typering beroepsgroepen

\begin{tabular}{lcccc}
\hline Typering & $\begin{array}{c}\text { erg laag } \\
\text { t.o.v. laag }\end{array}$ & $\begin{array}{c}\text { laag t.o.v. } \\
\text { gemiddeld }\end{array}$ & $\begin{array}{c}\text { gemiddeld } \\
\text { t.o.v. hoog }\end{array}$ & $\begin{array}{c}\text { hoog t.o.v. } \\
\text { erg hoog }\end{array}$ \\
\hline Percentage vrouwen & 5,74 & 16,60 & 46,63 & 73,38 \\
Percentage jongeren (15-29 jaar) & 6,70 & 16,07 & 25,20 & 35,17 \\
Percentage ouderen (50-64 jaar) & 12,67 & 17,17 & 23,34 & 32,82 \\
Percentage allochtonen naar etniciteit & 0,72 & 2,11 & 4,19 & 7,34 \\
Percentage allochtonen naar herkomst & 1,56 & 3,43 & 7,15 & 10,58 \\
Percentage deeltijdarbeid & 6,61 & 14,56 & 36,82 & 60,34 \\
Percentage zelfstandigen & 0,33 & 3,06 & 11,58 & 38,62 \\
Percentage flexibel werk & 1,86 & 4,00 & 7,43 & 17,52 \\
Percentage werknemers met vast werk & 81,13 & 91,96 & 95,94 & 98,14 \\
Uitwijkmogelijkheden bedrijfssectoren & 1,16 & 1,81 & 6,10 & 9,05 \\
Substitutiemogelijkheden & 3,14 & 5,97 & 10,38 & 15,92 \\
Conjunctuurgevoeligheid & 0,36 & 0,57 & 1,30 & 1,72 \\
Verwachte uitbreidingsvraag (\%) & -9 & -2 & 9 & 22 \\
Verwachte vervangingsvraag (\%) & 10 & 13 & 19 & 24 \\
Verwachte baanopeningen (\%) & 14 & 18 & 25 & 37 \\
\hline Typering & & & & enige t.o.v. \\
\end{tabular}


Tabel A.3

Grenzen kwalitatieve typering opleidingstypen

\begin{tabular}{|c|c|c|c|c|}
\hline Typering & $\begin{array}{l}\text { erg laag } \\
\text { t.o.v. laag }\end{array}$ & $\begin{array}{l}\text { laag t.o.v. } \\
\text { gemiddeld }\end{array}$ & $\begin{array}{l}\text { gemiddeld } \\
\text { t.o.v. hoog }\end{array}$ & $\begin{array}{l}\text { hoog t.o.v. } \\
\text { erg hoog }\end{array}$ \\
\hline Percentage vrouwen & 1,78 & 12,25 & 47,94 & 85,08 \\
\hline Percentage jongeren (15-29 jaar) & 9,74 & 18,14 & 27,11 & 35,96 \\
\hline Percentage ouderen (50-64 jaar) & 10,24 & 13,83 & 23,10 & 30,42 \\
\hline Percentage allochtonen naar etniciteit & 0,54 & 1,57 & 3,24 & 6,27 \\
\hline Percentage allochtonen naar herkomst & 1,31 & 3,04 & 5,57 & 9,80 \\
\hline Percentage deeltijdarbeid & 6,64 & 11,16 & 34,95 & 55,81 \\
\hline Percentage zelfstandigen & 4,70 & 6,23 & 12,70 & 25,12 \\
\hline Percentage flexibel werk & 2,93 & 4,25 & 7,81 & 11,47 \\
\hline Percentage werknemers met vast werk & 88,23 & 92,18 & 95,75 & 97,04 \\
\hline Uitwijkmogelijkheden beroepsgroepen & 2,94 & 4,65 & 10,77 & 18,43 \\
\hline Uitwijkmogelijkheden bedrijfssectoren & 2,16 & 3,78 & 9,39 & 14,53 \\
\hline Conjunctuurgevoeligheid & 0,64 & 0,79 & 1,00 & 1,17 \\
\hline Verwachte instroom (\%) & 8 & 15 & 26 & 35 \\
\hline Verwachte uitbreidingsvraag (\%) & -11 & 4 & 19 & 33 \\
\hline Verwachte vervangingsvraag (\%) & 8 & 13 & 20 & 25 \\
\hline Verwachte baanopeningen (\%) & 16 & 23 & 35 & 49 \\
\hline Typering & $\begin{array}{l}\text { zeer goed } \\
\text { t.o.v. goed }\end{array}$ & $\begin{array}{l}\text { goed t.o.v. } \\
\text { redelijk }\end{array}$ & $\begin{array}{l}\text { redelijk } \\
\text { t.o.v. matig }\end{array}$ & $\begin{array}{l}\text { matig t.o.v. } \\
\text { slecht }\end{array}$ \\
\hline ITA & 0,85 & 1,00 & 1,05 & 1,15 \\
\hline Typering & $\begin{array}{l}\text { zeer groot } \\
\text { t.o.v. groot }\end{array}$ & $\begin{array}{r}\text { groot t.o.v. } \\
\text { enige }\end{array}$ & $\begin{array}{l}\text { enige t.o.v. } \\
\text { vrijwel geen }\end{array}$ & $\begin{array}{l}\text { vrijwel geen } \\
\text { t.o.v. geen }\end{array}$ \\
\hline ITKP & 0,85 & 1,00 & 1,05 & 1,15 \\
\hline
\end{tabular}


Tabel A.4

Grenzen kwalitatieve typering opleidingstypen en -richtingen schoolverlatersinformatie

\begin{tabular}{lcrrr}
\hline Typering & $\begin{array}{c}\text { erg laag } \\
\text { t.o.v. laag }\end{array}$ & $\begin{array}{c}\text { laag t.o.v. } \\
\text { gemiddeld }\end{array}$ & $\begin{array}{r}\text { gemiddeld } \\
\text { t.o.v. hoog }\end{array}$ & $\begin{array}{r}\text { hoog t.o.v. } \\
\text { erg hoog }\end{array}$ \\
\hline Participatie in vervolgopleidingen studie & 3,32 & 9,69 & 19,32 & 36,73 \\
Participatie in vervolgopleidingen BBL & 1,45 & 3,17 & 9,21 & 37,39 \\
Percentage deeltijdarbeid & 4,17 & 7,74 & 38,78 & 58,92 \\
Percentage met een vast dienstverband & 47,29 & 63,65 & 78,36 & 90,49 \\
Gemiddeld bruto maandloon mavo/vmbo & 715 & 770 & 886 & 1.416 \\
Gemiddeld bruto mndloon havo/vwo/mbo & 1.219 & 1.337 & 1.600 & 1.848 \\
Gemiddeld bruto maandloon hbo & 1.712 & 1.888 & 2.011 & 2.071 \\
Gemiddeld bruto maandloon wo & 2.057 & 2.196 & 2.411 & 2.523 \\
Intredewerkloosheid van 4 mnd of langer & 1,54 & 3,17 & 6,73 & 11,28 \\
Percentage werkloosheid &, 86 & 1,72 & 3,64 & 6,82 \\
Onderbenutting & 11,73 & 20,92 & 41,03 & 57,64 \\
Functie buiten de eigen vakrichting & 11,68 & 21,88 & 39,27 & 52,28 \\
\hline
\end{tabular}

Er worden vijf typeringen onderscheiden: erg laag, laag, gemiddeld, hoog en erg hoog. Bij de Indicator toekomstige arbeidsmarktsituatie (ITA) betreft dit: zeer goed, goed, redelijk, matig, slecht en met betrekking tot de Indicator toekomstige kans op knelpunten in de personeelsvoorziening (ITKP): zeer groot, groot, enige, vrijwel geen, geen. Voor alle variabelen, met uitzondering van de ITA, de ITKP en de ITKB, zijn grenzen bepaald op basis van de kwantielenmethode (zie ook Wieling, De Grip en Willems, 1990). Bij de kwantielenmethode worden de grenzen zodanig bepaald dat $10 \%$ in de klasse erg laag valt, $20 \%$ in laag, $40 \%$ in gemiddeld, $20 \%$ in hoog en $10 \%$ in de klasse erg hoog. Voordat een procentuele variabele wordt gekwalificeerd, wordt het percentage afgerond. Voor de grenzen voor de ITKB is de procentuele verdeling van de opleidingstypen over de typeringen die voor de ITKP gelden bepaald. Deze verdeling is opgelegd aan de knelpunten naar beroep. Als bijvoorbeeld $34 \%$ van de opleidingen gekenmerkt wordt door zeer grote knelpunten, wordt de grens tussen grote en zeer grote knelpunten bij de ITKB zodanig vastgesteld dat $34 \%$ van de beroepen ook de typering zeer grote knelpunten krijgt. 


\section{Appendix B}

Onderstaand een overzicht van de opleidings- en beroepennamen die voor het grootste deel reeds in de eerdere uitgave De arbeidsmarkt naar opleiding en beroep tot 2004 gewijzigd zijn. Er wordt benadrukt dat er meestal slechts sprake is van een wijziging van de 'etiketten' van opleidingen en beroepen en niet van de onderliggende classificaties. Een uitzondering hierop zijn alle assistentenopleidingen binnen het MBO (niveau 1 volgens de Wet Educatie en Beroepsonderwijs). Deze assistentenopleidingen worden in de herziene versie van de Standaard- Onderwijs-Indeling 1978 door het CBS op VMBO-niveau ingedeeld. De ROAopleidingstypen waarop deze assistentenopleidingen betrekking hebben worden niet in de onderstaande tabel weergegeven.

Tabel B.1

Overzicht gewijzigde opleidingsnamen

\begin{tabular}{ll}
\hline Oude naam & Nieuwe naam \\
\hline MAVO & VMBO theorie \\
VBO landbouw en natuurlijke omgeving & VMBO landbouw en natuurlijke omgeving \\
VBO bouwtechniek & VMBO bouwtechniek \\
VBO installatietechniek & VMBO installatietechniek \\
VBO mechanische techniek & VMBO metaal: mechanische techniek \\
VBO fijnmechanische techniek & VMBO metaal: fijnmechanische techniek \\
VBO motorvoertuigentechniek & VMBO voertuigentechniek \\
VBO elektrotechniek & VMBO elektrotechniek \\
VBO grafische techniek & VMBO grafische techniek \\
VBO brood en banket & VMBO brood en banket \\
VBO horeca en levensmiddelentechniek & VMBO consumptief en levensmiddelentechniek \\
VBO vervoer & VMBO transport en logistiek \\
VBO administratie, handel en textiel & VMBO administratie, handel en mode \\
VBO verzorging & VMBO (uiterlijke) verzorging \\
VBO beveiliging & VMBO beveiliging \\
MBO/LLW vervoer & MBO vervoer en logistiek \\
HBO personeelswerk & HBO personeel en arbeid \\
WO farmacie & WO farmacie en medische biologie \\
\hline
\end{tabular}

Tabel B. 2

Overzicht gewijzigde beroepennamen

\begin{tabular}{ll}
\hline Oude naam & Nieuwe naam \\
\hline Sociaal-cultureel werkers & $\begin{array}{l}\text { Medewerkers sociaal-cultureel werk en personeel } \\
\text { en arbeid }\end{array}$ \\
$\begin{array}{l}\text { Sociaal raadslieden en hoofden personeels- } \\
\text { zaken }\end{array}$ & $\begin{array}{l}\text { Hoofden sociaal-cultureel werk en personeel en } \\
\text { arbeid }\end{array}$ \\
\hline
\end{tabular}

